\title{
Droughts in the area of Poland in recent centuries in the light of multi-proxy data
}

\author{
Rajmund Przybylak $^{1,6}$, Piotr Oliński ${ }^{2,6}$, Marcin Koprowski ${ }^{3,6}$, Janusz Filipiak $^{4}$, Aleksandra Pospieszyńska ${ }^{1,6}$, \\ Waldemar Chorążyczewski ${ }^{2,6}$, Radosław Puchałka ${ }^{3,6}$, and Henryk Paweł Dabrowski ${ }^{5}$ \\ ${ }^{1}$ Department of Meteorology and Climatology, Faculty of Earth Sciences and Spatial Management, \\ Nicolaus Copernicus University, Toruń, Poland \\ ${ }^{2}$ Department of Medieval History, Institute of History and Archival Sciences, Faculty of History, \\ Nicolaus Copernicus University, Torun, Poland \\ ${ }^{3}$ Department of Ecology and Biogeography, Faculty of Biological and Veterinary Sciences, \\ Nicolaus Copernicus University, Toruń, Poland \\ ${ }^{4}$ Department of Meteorology and Climatology, Institute of Geography, Faculty of Oceanography and Geography, \\ University of Gdańsk, Gdańsk, Poland \\ ${ }^{5}$ Dendroarchaeological Laboratory, Archaeological Museum in Biskupin, Biskupin, Poland \\ ${ }^{6}$ Centre for Climate Change Research, Nicolaus Copernicus University, Toruń, Poland
}

Correspondence: Rajmund Przybylak (rp11@umk.pl)

Received: 27 May 2019 - Discussion started: 11 June 2019

Revised: 30 January 2020 - Accepted: 31 January 2020 - Published: 1 April 2020

\begin{abstract}
The history of drought occurrence in Poland in the last millennium is poorly known. To improve this knowledge we have conducted a comprehensive analysis using both proxy data (documentary and dendrochronological) and instrumental measurements of precipitation. The paper presents the main features of droughts in Poland in recent centuries, including their frequency of occurrence, coverage, duration, and intensity. The reconstructions of droughts based on all the mentioned sources of data covered the period 996-2015. Examples of megadroughts were also chosen using documentary evidence, and some of them were described.

Various documentary sources have been used to identify droughts in the area of Poland in the period 1451-1800 and to estimate their intensity, spatial coverage, and duration. Twenty-two local chronologies of trees (pine, oak, and fir) from Poland were taken into account for detecting negative pointer years (exceptionally narrow rings). The delimitation of droughts based on instrumental data (eight long-term precipitation series) was conducted using two independent approaches (Standard Precipitation Index, SPI, calculated for 1-, 3-, and 24-month timescales, and a new method proposed by authors). For delimitation of droughts (dry months), the
\end{abstract}

criteria used were those proposed by McKee et al. (1993) and modified for the climate conditions of Poland by Łabędzki (2007).

More than 100 droughts were found in documentary sources in the period 1451-1800, including 17 megadroughts. A greater than average number of droughts were observed in the second halves of the 17 th century and the 18 th century in particular. Dendrochronological data confirmed this general tendency in the mentioned period.

Analysis of SPI (including its lowest values, i.e. droughts) showed that the long-term frequency of droughts in Poland has been stable in the last two or three centuries. Extreme and severe droughts were most frequent in the coastal part of Poland and in Silesia. Most droughts had a duration of 2 months (about $60 \%-70 \%$ ) or 3-4 months (10\%-20\%). Frequencies of droughts with a duration of 5-or-more months were lower than $10 \%$. The frequency of droughts of all categories in Poland in the instrumental period 1722-2015 was greatest in winter, while in the documentary evidence (14511800) droughts in this season are rarely mentioned.

The occurrence of negative pointer years (a good proxy for droughts) was compared with droughts delimited based on documentary and instrumental data. A good correspondence 
was found between the timing of occurrence of droughts identified using all three kinds of data (sources).

\section{Introduction}

The increase of the rate of global warming that has been observed in recent decades also influences characteristic changes in the occurrence and intensity of precipitation (IPCC, 2013). Although precipitation totals are slightly greater from year to year in some regions, frequency of precipitation is getting lower while its intensity is increasing. As a result, breaks between precipitation episodes are getting longer and longer, which significantly favours the occurrence of droughts. The majority of statistical analyses presenting results of drought frequency and intensity averaged for the entire world (Dai and Trenberth, 1998; Dai et al., 2004; Dai, 2011a, b, 2013; IPCC, 2013) and its different regions (see Held et al., 2005; Alexander et al., 2006; Bartholy and Pongracz, 2007; Łabędzki, 2007; Brázdil et al., 2009; Seneviratne et al., 2012; NAS, 2013; Miles et al., 2015; Osuch et al., 2016; Bąk and Kubiak-Wójcicka, 2017; Brázdil et al., 2018) usually confirm their rising tendencies, in particular in more recent decades. On the other hand, some authors document that this change for the entire globe is not as clear as is presented in some above-mentioned publications, and it depends among others on the drought metrics used (Sheffield et al., 2012; Greve et al., 2014, and references therein). For example, Sheffield et al. (2012) argue that overestimation of the rate of change of global droughts is related to the shortcomings (simplifications) of the Palmer Drought Severity Index (PDSI) used for this purpose. They write the following: "The simplicity of the PDSI, which is calculated from a simple water-balance model forced by monthly precipitation and temperature data, makes it an attractive tool in large-scale drought assessments, but may give biased results in the context of climate change." Thus, the reliable estimate of global tendencies in the occurrence and intensity of droughts still needs more research. Nevertheless, a greater or lesser increase in frequency of droughts in many regions have been observed in recent decades. Moreover, climatic models project that this tendency probably will be more common and clear in the future world. The IPCC (2013) report concludes that droughts will be not only more frequent but also more intense in many regions, particularly in areas with dry conditions in today's climate. For this reason, the study of drought occurrence and its intensity is very important, in particular when its manifold negative socio-economic consequences are taken into account. Many aspects dealing with drought (definition; kinds - meteorological, agricultural, hydrological, socio-economic; quantitative ways of measurement; socio-economic consequences; etc.) were described recently in many publications (e.g. Wilhite and Glantz, 1985; Tate and Gustard, 2000; Herweijer et al., 2007; Mishra and Singh, 2010; Dai, 2011a; Brázdil et al., 2013, 2018; IPCC,
2014; Fragoso et al., 2018; White et al., 2018), and therefore a brief overview is omitted here.

To estimate how unprecedented the scale of climate drying in recent decades is, a longer perspective is needed. Therefore, in recent decades quite a lot of drought reconstructions encompassing almost the entire millennium, or the shorter historical pre-industrial period, were constructed for different greater or smaller regions (e.g. Inglot, 1968; Piervitali and Colacino, 2001; Cook et al., 2004, 2010, 2015; Herweijer et al., 2007; Pfister et al., 2006; Brewer et al., 2007; Domínguez-Castro et al., 2008, 2010; Woodhouse et al., 2010; Brázdil et al., 2013, 2016, 2018 (see references herein); Dobrovolný et al., 2015; Fragoso et al., 2018; Hanel et al., 2018).

What is the state of knowledge about drought occurrence and intensity in Poland - the area that is the object of our studies in this paper? It must be said that for the instrumental period, and in particular for the period after World War II, the knowledge is good. Papers have been published analysing the following: (1) classification of drought types and the development of drought indices (Bąk and Łabędzki, 2002; Łabędzki, 2007; Łabędzki and Kanecka-Geszke, 2009; Tokarczyk, 2013; Łabędzki and Bąk, 2014); (2) tendencies in drought occurrence and intensity (Farat et al., 1998; Magier et al., 2000; Łabędzki, 2007; Kalbarczyk, 2010; Bartczak et al., 2014; Radzka, 2015; Wypych et al., 2015; Bąk and Kubiak-Wójcicka, 2017); (3) monitoring of drought conditions (Łabędzki, 2006; Doroszewski et al., 2008, 2012; Tokarczyk and Szalińska, 2013; IMGW, 2014; ITP, 2014; Łabędzki and Bąk, 2014); and (4) drought hazard assessment for periods when observations are available (Łabędzki, 2009; Tokarczyk and Szalińska, 2014). In recent years the influence of future climate change on the occurrence of droughts in Poland in the 21st century has also been addressed (Liszewska et al., 2012; Osuch et al., 2012, 2016). On the other hand, little is known about drought occurrence in the pre-instrumental and early instrumental periods in Poland. Generally, only one attempt to form a drought chronology for the 16th to mid-19th century was proposed based on documentary evidence (Inglot, 1968).

Drought is one of the most stressful factors for trees (Vitas, 2001; Allen et al., 2010; Sohar et al., 2013). The measurement of tree ring widths is one of the ways to study the effect of climate parameters on trees (Zielski et al., 2010). Some factors such as frost or summer drought may have an immediate effect on ring width, whereas other factors, such as winter drought, may have a delayed effect on ring widths. This delayed effect occurs because the meristematic tissues are dormant during the winter months in temperate and cold climates. The effect of different factors is seen as variations in ring size and structure, which change systematically or vary slowly throughout the life of the tree (Fritts, 1976). The effect of drought on tree rings is observed as narrow rings (Koprowski et al., 2012; Opała, 2015). The relationships are significant enough to reconstruct drought in tem- 
perate climates and in cold regions like Finland (Helama and Lindholm, 2003), Sweden (Seftigen et al., 2013), and Czech Republic (Dobrovolný et al., 2015). Therefore, we have assumed that information derived from tree rings can complement the existing knowledge about past droughts in Poland. According to studies by Somorowska (2016), the effect of drought extends from the south-west towards the central part of the country and, in some cases, to the north-east of Poland. Another study suggests that in the future some of the highest probability of drought occurrence can be in the central part with the lowest probability in south-eastern Poland (Diakowska et al., 2018).

Although in the last three decades many climate reconstructions for the last millennium have been conducted for Poland (see Przybylak et al., 2005, or Przybylak, 2016, for a review), droughts were not analysed. Therefore, to fill this important gap we decided to investigate them in a more detailed manner than was done by Inglot's team. Moreover, for this purpose we used more sorts of proxy data (not only documentary but also dendrochronological). The reconstructions of droughts based on all the mentioned sources of data covered the period 996-2015. Thus, the main aim of this paper is to present the main features of drought occurrence, duration, and intensity in the area of Poland in this period. Section 2 describes all the kinds of data used and their quality. Section 3 addresses the methods used in this study, including drought indices. Section 4 presents the results of three reconstructions of droughts derived from (1) documentary, (2) instrumental, and (3) dendrochronological data. Examples of megadroughts are also analysed here. The results obtained are discussed in Sect. 5, and the main conclusions are in the last section.

\section{Data}

\subsection{Documentary data}

Records on drought for historical reconstruction of climate can be found in many different historical sources from Poland. Their number has significantly increased since the mid-15th century, which is why the mid-15th century was adopted as the initial chronological boundary for the reconstruction of the number and intensity of droughts in the Polish territory using documentary evidence. Below we describe the types of historical sources used to reconstruct droughts in Poland.

Records of droughts in the Polish territory are most often found in narrative sources - chronicles, yearbooks, memoirs, diaries, and travel accounts. The information included in these sources has a varying degree of accuracy. Often only one account concerning drought appeared, e.g. "magna siccitas". In many of the records, however, more detailed descriptions of the course of droughts and accompanying phenomena were given. In the ancient sources droughts were described above all when their manifestations were very clear and when they had an impact on economic and social life. Another group of sources used by us is daily records that have the character of meteorological observations. Sometimes they were prepared by scholars, such as professors Marcin Biem (ca. 1470-1540) and Michał of Wiślica (1499-1575) of the Jagiellonian University, who conducted such observations in Kraków from 1499 to 1531 and from 1534 to 1551 (Limanówka, 2001), or townsmen with scientific ambitions such as Gottfried Reyger (17041788), who began his observations in Gdańsk in 1721 as a 17-year-old man and continued them later, among others as a member of the Naturforschende Gesellschaft in Gdańsk until 1786 (Filipiak et al., 2019). Sometimes daily observations were conducted by amateurs; the best examples of which are the records of the Polish nobleman from the eastern territories of the Polish-Lithuanian Commonwealth, Jan Antoni Chrapowicki, which were conducted for the years 1656-1685 (Nowosad et al., 2007). Sources of this kind are nonetheless relatively rare.

The correspondence, the manuscript press ("written newspapers"), and printed press were also used in the reconstruction of droughts. In the case of written newspapers, these are often records similar to those that appear in chronicles. They were drawn up on a regular basis, which increases their credibility. They provided news from the region, as well as information coming from other countries, e.g. from Lviv, from which a news writer in 1698 wrote: "w tych krajach chaniebnie [! - emphasis added] susze wielkie, dla których na zimę bardzo mało siano, bo nie podobna lemieszem ukroić ziemię" [in English "in these countries shamefully there are great droughts, for which reason we sowed very little for the winter, because you cannot cut the land with the ploughshare"] (Maliszewski, 2018). Other sources that turned out to be useful for the implementation of our project were official files (e.g. protocols from meetings of the regional dietines and the Parliament (Sejm), treasury registers, and inspection reports) and documenting activities undertaken, e.g. in connection with droughts and fires. They reported requests for financial support in connection with drought, tax exemption requests, etc. In economic files one can find explanations for low harvests, which occurred for example due to drought. There are a few sources concerning religious behaviours in which, for example, the organisation of prayers asking for rain or describing the end of a drought were described. When such accounts appeared, it can be assumed that the drought must have been severe for people and the environment.

In addition to the above-mentioned historical sources collected during the queries in Polish, Lithuanian, Ukrainian, and German archives, the authors used several published collections (of varied quality) of historical sources concerning the climate research in the period from the 10th century to the end of the 18th century for Poland, central Europe, or selected regions of central Europe. They include the period from the 10th century to the end of the 16th 
century (Girguś et al., 1965), the Middle Ages (Malewicz, 1980), 1450-1586 (Walawender, 1935), the years 1648-1696 (Namaczyńska, 1937), and 1772-1848 (Szewczuk, 1939). In the last 20 years, two databases containing over 10000 weather records were made available in universities in Torun and Wrocław as part of cooperation between climatologists and historians. They have been used many times to study Poland's climate in historical times (Wójcik et al., 2000; Przybylak et al., 2001, 2004, 2005, 2010; Przybylak, 2011, 2016); they have also contributed to widening the scope of this research.

To sum up, for the purpose of this research over 200 accounts referring directly to droughts and prolonged shortages of rainfall were used, along with a few hundred more descriptions from everyday weather observations, the use and critical elaboration of which allowed periods of drought to be indicated. The state of the preservation of sources for particular periods and for individual regions is uneven. Most of them describe droughts in Silesia, Pomerania, and Lesser Poland. A large number of entries refer to droughts affecting the whole territory of Poland. In the case of Silesia, the distribution of sources is fairly even for the whole period; in the case of other regions their number increases with successive ages. The only exception is the first half of the 17th century, in which the number of preserved records is definitely smaller. To some extent, this was affected by the losses in the state of preserved sources that occurred during the Swedish invasion of Polish territories in 1655-1660. Many sources from the first half of the 17th century were then destroyed as a result of military actions.

The accuracy scale of the collected information is variable. Some accounts provide quite precise information concerning the duration of the drought, even to the accuracy of $1 \mathrm{~d}$, while others are definitely more general - they only indicate the existence of a drought in a given year. It very often occurs that one drought is described in several, or sometimes even several dozen, independent sources, which confirms its high intensity.

To assess the credibility of individual records, it was necessary to conduct a critical source analysis, in which it turned out that sometimes even short accounts provided very important and reliable information, while other records with a similar structure proved to be wrong due to the fact that, for example, the year of the occurrence of the drought was changed (e.g. by 1 year) when the information was being copied from another, earlier source. The sources containing daily records, as in the case of the memoirs of J. A. Chrapowicki (1988) or Reyger $(1770,1788)$, required a different treatment. It was possible to count the days with precipitation and without precipitation along with a very precise indication of the duration of the droughts.

\subsection{Dendrochronological data}

We used 22 chronologies (17 oak chronologies, 5 pine chronologies, and 1 fir chronology) from different locations in Poland to detect pointer years (Table 1, Fig. 1). Table 1 presents a list of them, including also time coverage and sources. As shown in Table 1, the longest chronology available to us covers the years 996-1986, and it was constructed for western Pomerania (site 5). For Upper Silesia (sites 16 and 18) and Lesser Poland (sites 21 and 22), the pointer years were detected by Opała and Mendecki (2014) and Opała (2015) and by Szychowska-Krąiec (2010), respectively (Table 1, Fig. 1).

\subsection{Instrumental data}

\subsubsection{Isolated series}

The number of known precipitation series whose beginnings date back to earlier than the 20th century is very limited. There are only a dozen of those that begun before 1800 . Efforts to organise meteorological measurements in Poland were made relatively early in comparison to other European countries. The country's complicated history (e.g. many wars and changes of borders) has resulted in the loss of the majority of sources collected in the archives, and in many cases irretrievably. However, actions to restore the long measurement series based on the discovered collections have been taken for a few selected locations.

The oldest surviving results of instrumental precipitation series in Poland come from Gdańsk and are dated to the first half of the 18th century. In January 1739, Michael Christoph Hanov, a mathematician and physician, started daily observations of weather phenomena and measurements of a dozen meteorological elements, including precipitation. The results of his efforts were published in the newspaper Danziger Erfahrungen on a weekly basis. Hanov presented the complete series in his manuscript Wetter Beobachtungen in Danzig 1739-1773.

Hanov's instrumental series was accompanied by the notes from a weather chronicle authored by Gottfried Reyger. He started systematic observations of the weather in Gdańsk in December 1721 and carried them out until mid-1786. The results of observations were used mainly to study how climate affects the development of plants. Reyger published the outcomes of his studies in Die Beschaffenheit der Witterung in Danzig vom Jahr 1722 bis 1769 beobachtet nach ihren Veränderungen und Ursachen erwogen (Reyger, 1770) and in Die Beschaffenheit der Witterung in Danzig. Zweyter Theil vom Jahr 1770 bis 1786, nebst Zustätzen zur Danziger Flora (Reyger, 1788).

Reyger usually presented remarks on general weather conditions supplemented by some additional data. Months were usually described in a qualitative, even aggregate, manner. His notes were very detailed and even the weather of the particular days or weeks was very often characterised. Reyger 
Table 1. Basic characteristics of the chronologies used for pointer year analysis. Locations of natural-forest regions (Zielony and Kliczkowska, 2010) and sites are shown in Fig. 1. EPS - expressed population signal, rbar.tot - the mean of all correlations between different cores.

\begin{tabular}{|c|c|c|c|c|c|c|c|}
\hline $\begin{array}{l}\text { Site } \\
\text { number }\end{array}$ & Site name & Time span & $\begin{array}{r}\text { Number } \\
\text { of } \\
\text { samples }\end{array}$ & EPS & rbar.tot & Species & $\begin{array}{l}\text { Source } \\
\text { Last access to data bases: } 16 \text { March } 2020\end{array}$ \\
\hline \multicolumn{8}{|c|}{ Region I (Baltic province) } \\
\hline Site 1 & Koszalin & $1782-1987$ & 22 & 0.899 & 0.339 & Oak & $\begin{array}{l}\text { https://www.ncdc.noaa.gov/paleo-search/study/5219 } \\
\text { (Ważny, 1990) }\end{array}$ \\
\hline Site 2 & Gdańsk & $1762-1986$ & 45 & 0.887 & 0.192 & Oak & $\begin{array}{l}\text { https://www.ncdc.noaa.gov/paleo-search/study/5215 } \\
\text { (Ważny, 1990) }\end{array}$ \\
\hline Site 3 & Wolin & $1554-1987$ & 23 & 0.877 & 0.318 & Oak & $\begin{array}{l}\text { https://www.ncdc.noaa.gov/paleo-search/study/5224 } \\
\text { (Ważny, 1990) }\end{array}$ \\
\hline Site 4 & Gdańsk & $1175-1396$ & 13 & 0.579 & 0.388 & Oak & Henryk Paweł Dąbrowski, unpublished \\
\hline Site 5 & western Pomerania & $996-1986$ & 205 & 0.907 & 0.250 & Oak & $\begin{array}{l}\text { https://www.ncdc.noaa.gov/paleo-search/study/5214 } \\
\text { (Ważny, 1990) }\end{array}$ \\
\hline \multicolumn{8}{|c|}{ Region II (Masuria-Podlasie province) } \\
\hline Site 6 & Gołdap & $1871-1987$ & 22 & 0.941 & 0.472 & Oak & $\begin{array}{l}\text { https://www.ncdc.noaa.gov/paleo-search/study/5216 } \\
\text { (Ważny, 1990) }\end{array}$ \\
\hline Site 7 & Suwałki & $1861-1987$ & 19 & 0.872 & 0.303 & Oak & $\begin{array}{l}\text { https://www.ncdc.noaa.gov/paleo-search/study/5221 } \\
\text { (Ważny, 1990) }\end{array}$ \\
\hline Site 8 & Hajnówka & $1720-1985$ & 19 & 0.851 & 0.314 & Oak & $\begin{array}{l}\text { https://www.ncdc.noaa.gov/paleo-search/study/5217 } \\
\text { (Ważny, 1990) }\end{array}$ \\
\hline \multicolumn{8}{|c|}{ Region III (Greater Poland-Pomerania province) } \\
\hline Site 9 & Poznań & $1836-1987$ & 17 & 0.904 & 0.385 & Oak & $\begin{array}{l}\text { https://www.ncdc.noaa.gov/paleo-search/study/5220 } \\
\text { (Ważny, 1990) }\end{array}$ \\
\hline Site 10 & Zielona Góra & $1774-1987$ & 19 & 0.876 & 0.330 & Oak & $\begin{array}{l}\text { https://www.ncdc.noaa.gov/paleo-search/study/5226 } \\
\text { (Ważny, 1990) }\end{array}$ \\
\hline Site 11 & Toruń & 1714-2015 & 48 & 0.886 & 0.335 & Oak & Puchałka et al. (2016) \\
\hline Site 12 & Tuchola & $1249-1490$ & 7 & 0.054 & 0.347 & Pine & Henryk Paweł Dąbrowski, unpublished \\
\hline Site 13 & Kuyavia-Pomerania & 1169-2015 & 247 & 0.816 & 0.195 & Pine & Koprowski et al. (2012) \\
\hline Site 14 & Chojnice & $1100-1468$ & 21 & 0.688 & 0.327 & Oak & Henryk Paweł Dąbrowski, unpublished \\
\hline \multicolumn{8}{|c|}{ Region IV (Masovia-Podlasie province) } \\
\hline Site 15 & Warszawa & $1690-1985$ & 19 & 0.850 & 0.291 & Oak & $\begin{array}{l}\text { https://www.ncdc.noaa.gov/paleo-search/study/5223 } \\
\text { (Ważny, 1990) }\end{array}$ \\
\hline \multicolumn{8}{|c|}{ Region V (Silesia province) } \\
\hline Site 16 & Upper Silesia & 1770-2010 & 80 & $\begin{array}{c}0.880 \\
\text { (average) }\end{array}$ & $\begin{array}{l}\text { Correlation } \\
0.530\end{array}$ & $\begin{array}{l}\text { Pine and } \\
\text { oak }\end{array}$ & Opała and Mendecki (2014) \\
\hline Site 17 & Wrocław & $1727-1987$ & 22 & 0.870 & 0.327 & Oak & $\begin{array}{l}\text { https://www.ncdc.noaa.gov/paleo-search/study/5225 } \\
\text { (Ważny, 1990) }\end{array}$ \\
\hline Site 18 & Upper Silesia & 1568-2010 & 178 & 0.850 & $\begin{array}{l}\text { Correlation } \\
\quad 0.510\end{array}$ & Pine & Opała (2015) \\
\hline \multicolumn{8}{|c|}{ Region VI (Lesser Poland province) } \\
\hline Site 19 & Kraków & $1792-1986$ & 29 & 0.906 & 0.361 & Oak & $\begin{array}{l}\text { https://www.ncdc.noaa.gov/paleo-search/study/5213 } \\
\text { (Ważny, 1990) }\end{array}$ \\
\hline Site 20 & Kosobudy & $1782-1989$ & 22 & 0.937 & 0.448 & Oak & $\begin{array}{l}\text { https://www.ncdc.noaa.gov/paleo-search/study/5218 } \\
\text { (Ważny, 1990) }\end{array}$ \\
\hline Site 21 & Lesser Poland & 1109-2004 & 238 & No data & No data & Pine & Szychowska-Krąpiec (2010) \\
\hline Site 22 & Lesser Poland & 1109-2006 & 560 & No data & No data & Fir & Szychowska-Krąpiec (2010) \\
\hline
\end{tabular}




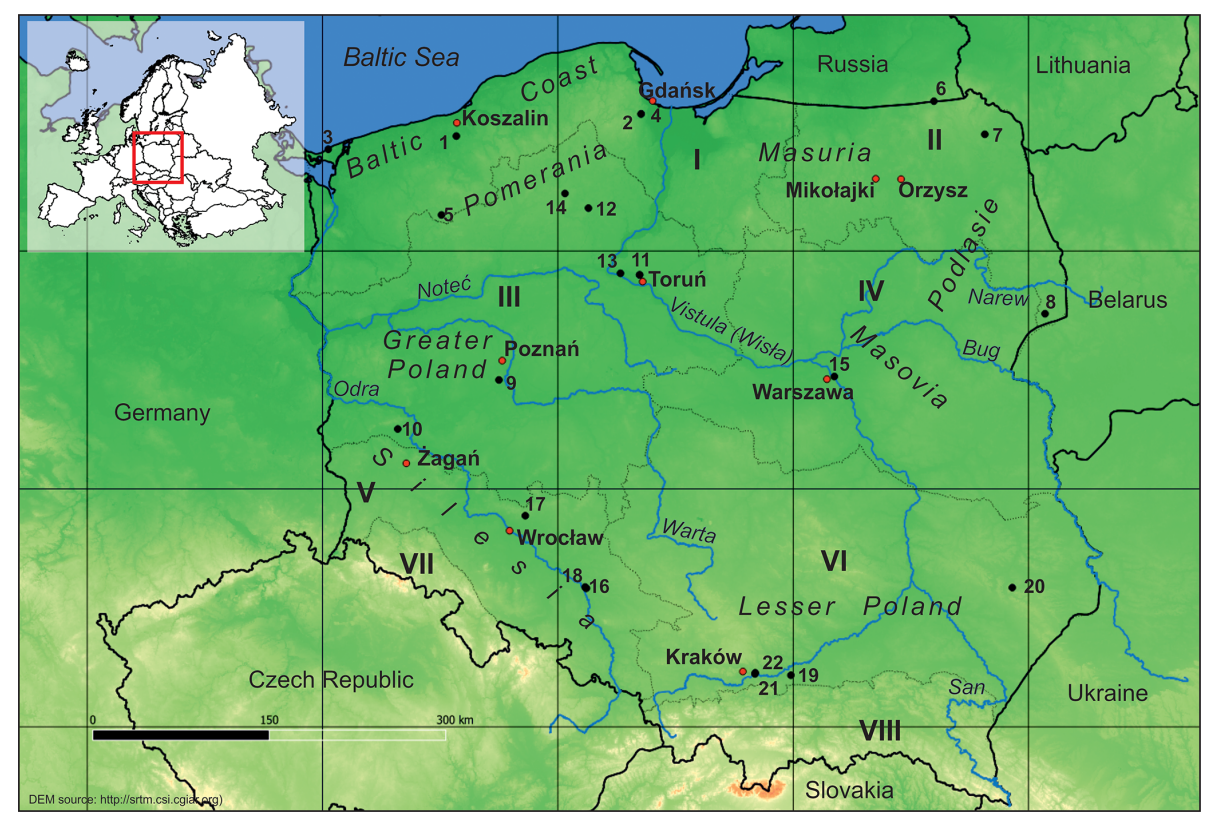

Figure 1. Location of dendrochronological sites and natural-forest regions (black dots and black dotted lines, respectively; for more details see Table 1) as well as meteorological series (red dots) and geographical regions (for more details see Table 2) used in the study.

paid special attention to particularly important weather and climate phenomena (heavy rain, floods, droughts, and heat and cold waves). His notes after 1783 (Hanov's death) were more accurate. Despite the lack of measured values of precipitation, detailed data on the monthly number of rainfall and snowfall were presented (for more details including the reconstruction of the air temperature and precipitation series since 1721; see Filipiak et al., 2019). Some sources suggest an even earlier date for the beginning of Reyger's instrumental observations (Hellmann, 1883, after Rojecki, 1965). Besides the short description in the mentioned literature no other proof of such activity is available.

\subsubsection{Long-term continuous series}

The series from Wrocław (formerly Breslau) that commenced in 1791 (Bryś and Bryś, 2010) is the longest continuous Polish precipitation series. For the purpose of the present paper we prolonged this series until 1781 based on precipitation measurements in Żagan (formerly Sagan) within the Mannheim network of stations established for Europe and North America by the Palatine Meteorological Society in 1780 (Przybylak et al., 2014). The cited authors proved that there exist high correlations between the precipitation series from both places. Source data from Żagań were taken from the publication Ephemerides Societatis Meteorologicae Palatinae, 1783-1795. In addition, we must say that the Wrocław series is the only continuous series to have begun before 1800 in the area currently belonging to Poland. The best-known long-term climatological series in Poland is the one from Kraków that commenced in 1792. The work on completing the collections of the Kraków series continue till the present day, the effect of which are reconstructions of monthly values of precipitation sums since 1863 (Twardosz, 2005, 2007). As for other Polish cities, Lorenc (2000) performed a homogenisation of series of monthly precipitation totals of Warszawa (Warsaw) since 1813. Miętus (2002) reconstructed atmospheric precipitation sums from Koszalin (formerly Köslin) since 1848. In another paper, Kożuchowski and Miętus (1996) presented series of precipitation totals in Szczecin (formerly Stettin) since 1848. In 2011 a reconstruction was performed for the precipitation series from Gdańsk in 1880-2008 (further extended to 1851) (Filipiak, 2011). During the CLIMPOL project ("Climate of northern Poland during the last 1000 years: Constraining the future with the past") Filipiak reconstructed the series of monthly precipitation totals since 1891 for Lake Żabińskie in NE Poland $\left(54^{\circ} 07^{\prime} \mathrm{N}, 21^{\circ} 59^{\prime} \mathrm{E}\right)$ (LarocqueTobler et al., 2015). Further, the series of Orzysz (formerly Arys) and Mikołajki (formerly Nikolaiken), also in NE Poland, were collected for the years 1830-1904 and since 1889 , respectively. As both stations are located very close to one another (approximately $20 \mathrm{~km}$ ), these two series have data very much in common. The correlation coefficient calculated for the overlapping periods 1889-1904 and 19812015 exceeds 0.85 . Thus we decided to combine both series: data from Orzysz cover the period between 1830 and 1890 and the later data come from Mikołajki. A couple of series, e.g. Poznań (formerly Posen), Toruń (formerly Thorn), Racibórz (formerly Ratibor, Silesia), and Śnieżka (formerly Schneekoppe, Sudety mountains), began around the middle of the 19th century and are available in yearbooks that were 
initially released by the Royal Prussian Meteorological Institute (Königlich Preussischen Meteorologischen Institut), then since 1918 by the Polish National Meteorological and Hydrological Service (PIM until 1945, further PIHM, after 1972, IMGW, and currently IMGW-PIB). The complete list of instrumental series employed in the current research and their sources is presented in Table 2.

\section{Methods}

\subsection{Documentary data}

The collected historical sources informing about droughts were evaluated according to a three-level scale, taking into account, first of all, signalled manifestations and consequences of the drought and its duration. The droughts were divided into "extreme", "severe", and "moderate".

Extreme droughts (index -3) constituted periods of no rainfall or very scarce rainfall that were long-lasting - they lasted at least one season (2-3 months or more). The principle that extreme droughts should be recorded in sources from two regions or more was adopted; even in view of the absence of sources this allows us to assume that these were droughts of an exceptional nature, having been noted by many writers. Such an extreme drought of 1473 was described, among others, in the Annals by Jan Długosz and, for example, in the local chronicle of Wrocław by Nicolaus Pol. When the source information indicated an extreme drought but at the same time there appeared information, for example, about the high level of water or floods, which may have indicated heavier precipitation especially in the summer season, it was concluded that no extreme drought had taken place. In agricultural terms, extreme droughts contributed to much earlier cereal harvests; they often seriously threatened the growth and size of yield, as was mentioned in the sources. Descriptions of extreme droughts usually contain several permanent elements: severe water shortages, fires, the destruction of crops; sometimes there also appeared records about the fact that people did not remember a similar drought having occurred in their lifetime. These droughts caused water reservoirs - ponds and lakes - to dry up completely. Sometimes, and probably in an exaggerated way, sources reported the drying up of smaller rivers.

During extreme droughts, there were frequent records of persistent, very low water levels in the largest rivers - the Odra and the Wisła (Table 3). The result was a lack of water for people and animals, halting the work of water mills in whole provinces. The consequences of drought were underlined - particularly a lack of food and high prices. Numerous fires broke out in cities, villages, and forests. The sources used such phrases as "estas ferventissima et siccitas inaudita" [very hot and incredible summer drought], "sidere solari plus solito effervescente et nullas dante pluvias" [extraordinary sun heat and continuous drought], "unaufhörlich trockene Witterung" [unbelievably dry weather] and "alle
Bäche vertrockneten" [all streams dried up] and the like, underlining the extreme nature of the drought. Superlative adjectives were very often used.

Severe droughts that lasted almost the whole season but no longer (up to about 2-3 months) were marked with the index -2 . When they fell in the spring period of plant growth, they influenced the quality of the harvest. It was frequently reported that crops had dried up in fields, on hillslopes especially exposed to the sun, and with less-humid soils than in the valleys. Those droughts made it difficult for people and animals to obtain water; sometimes they prevented the work of some mills on the rivers, but they did not paralyse grain milling in the entire province. Droughts were incidentally related to forests and meadows. Efforts were made to focus on those descriptions in which at least two of the phenomena described above appeared. There was no requirement to describe such droughts in more sources. Examples of descriptions of severe droughts in different historical sources are presented in Table 4.

Moderate droughts (marked with the index -1) were ones whose appearance was noticeable by people; however, they lasted for a relatively short period of time and affected crops to a limited extent. This group also includes records that seem incidental, are not confirmed in other sources, or may indicate a small range of drought, yet they were significant enough to be recorded in the sources (Table 5). There is no record of consequences (including economic ones). In the description of the drought, a superlative adjective is not used. There appear such expressions as "dürrer Sommer" [dry summer]. In other sources, in reference to the same period of time, there may be records that indicate, for example, rain instead of drought.

Therefore, relatively long periods of 50 years were adopted to assess long-term (secular) frequencies. It should also be added that most probably in the oldest sources from the 15 th -17 th centuries, primarily droughts of considerable intensity were recorded (i.e. droughts referred to by us as severe and extreme), while those of a smaller scale (moderate) were omitted. This is due to the nature of the sources at the time and the relatively modest number of such records. Therefore, it can be assumed that droughts of -1 , and probably in some part also droughts of -2 may be underestimated from the perspective of historical sources. The sources for the 18 th century are definitely more precise. In the 18th century, the duration of the drought as well as its territorial range can often be very precisely determined, though not always.

\subsection{Dendrochronological data}

We hypothesised that narrow tree rings are linked with drought. The limited access to water during the vegetation season leads to a water deficit in trees and as a consequence the cambium activity decreases and produces fewer cells, which is positively correlated with tree-ring widths (Liang et al., 2013). De-trending of the chronology was done with 
Table 2. List of sites, their locations, and periods covered by series of monthly precipitation totals used in the paper.

\begin{tabular}{|c|c|c|c|c|c|}
\hline No. & Station & $\begin{array}{l}\text { Geographical } \\
\text { region }\end{array}$ & $\begin{array}{l}\text { Observation } \\
\text { period }\end{array}$ & Location $(\varphi, \lambda ; h)$ & Sources of data \\
\hline \multicolumn{6}{|c|}{ Isolated series } \\
\hline $1 \mathrm{a}$ & Gdańsk* & 1 & $1722-1786$ & $\begin{array}{l}54^{\circ} 20^{\prime} \mathrm{N}, 18^{\circ} 40^{\prime} \mathrm{E} \\
13 \mathrm{~m} \text { a.s.l. }\end{array}$ & $\begin{array}{l}\text { Reyger }(1770,1788) \text { and Filipiak et al. (2019) for the periods } 1722-1738 \\
\text { and 1773-1786; Hanov (1773) for the period 1739-1773 }\end{array}$ \\
\hline \multicolumn{6}{|c|}{ Long-term continuous series } \\
\hline $1 \mathrm{~b}$ & Gdańsk & 1 & $1851-2015$ & $\begin{array}{l}54^{\circ} 20^{\prime} \mathrm{N}, 18^{\circ} 40^{\prime} \mathrm{E} \\
13 \mathrm{~m} \text { a.s.l. }\end{array}$ & Filipiak (2011) for the whole period \\
\hline 2 & Koszalin & 1 & $1851-2015$ & $\begin{array}{l}54^{\circ} 12^{\prime} \mathrm{N}, 16^{\circ} 11^{\prime} \mathrm{E} \\
46 \mathrm{~m} \text { a.s.l. }\end{array}$ & $\begin{array}{l}\text { Reichsamt für Wetterdienst (1939) for the period 1851-1930 corrected } \\
\text { by Miętus (2002); Miętus (2002) for the period 1931-1990; } \\
\text { Central Database of Historical Data of IMGW-PIB (Polish National } \\
\text { Meteorological and Hydrological Service) for years 1991-2015 }\end{array}$ \\
\hline $3 a$ & Orzysz & 2 & 1830-1890 & $\begin{array}{l}53^{\circ} 48^{\prime} \mathrm{N}, 21^{\circ} 56^{\prime} \mathrm{E} \\
122 \mathrm{~m} \text { a.s.l. }\end{array}$ & $\begin{array}{l}\text { Dove (1851) for the period 1830-1850; Reichsamt für } \\
\text { Wetterdienst (1939) for the years 1851-1904 }\end{array}$ \\
\hline $3 b$ & Mikołajki & 2 & $1891-2015$ & $\begin{array}{l}53^{\circ} 48^{\prime} \mathrm{N}, 21^{\circ} 34^{\prime} \mathrm{E} \\
116 \mathrm{~m} \text { a.s.l. }\end{array}$ & Central Database of Historical Data of IMGW-PIB for the whole period \\
\hline 4 & Toruń & 3 & $1871-2015$ & $\begin{array}{l}53^{\circ} 01^{\prime} \mathrm{N}, 18^{\circ} 36^{\prime} \mathrm{E} \\
60 \mathrm{~m} \text { a.s.l. }\end{array}$ & $\begin{array}{l}\text { Pospieszyńska and Przybylak (2013) for the period 1871-2010; } \\
\text { Central Database of Historical Data of IMGW-PIB for years 2011-2015 }\end{array}$ \\
\hline 5 & Poznań & 3 & $1848-2015$ & $\begin{array}{l}52^{\circ} 25^{\prime} \mathrm{N}, 16^{\circ} 56^{\prime} \mathrm{E} \\
66 \mathrm{~m} \text { a.s.l. }\end{array}$ & $\begin{array}{l}\text { Dove (1851) for the period 1848-1850; Central Database of Historical } \\
\text { Data of IMGW-PIB for the years 1851-2015 }\end{array}$ \\
\hline 6 & Warszawa & 4 & $1813-2015$ & $\begin{array}{l}52^{\circ} 13^{\prime} \mathrm{N}, 21^{\circ} 01^{\prime} \mathrm{E} \\
97 \text { m a.s.l. }\end{array}$ & $\begin{array}{l}\text { Lorenc }(2000,2007) \text { for the years } 1813-1999 \text {; Central Database of } \\
\text { Historical Data of IMGW-PIB for the years 2000-2015 }\end{array}$ \\
\hline $7 \mathrm{a}$ & Żagań & 5 & $1781-1790$ & $\begin{array}{l}51^{\circ} 37^{\prime} \mathrm{N}, 15^{\circ} 19^{\prime} \mathrm{E} \\
102 \mathrm{~m} \text { a.s.l. }\end{array}$ & $\begin{array}{l}\text { Ephemerides Societatis Meteorologicae Palatinae, 1783-1795 } \\
\text { for the whole period }\end{array}$ \\
\hline $7 \mathrm{~b}$ & Wrocław & 5 & 1791-2015 & $\begin{array}{l}51^{\circ} 07^{\prime} \mathrm{N}, 17^{\circ} 05^{\prime} \mathrm{E} \\
120 \mathrm{~m} \text { a.s.l. }\end{array}$ & $\begin{array}{l}\text { Bryś and Bryś (2010) for the years 1791-2000; Central Database of } \\
\text { Historical Data of IMGW-PIB for the years 2001-2015 }\end{array}$ \\
\hline 8 & Kraków & 6 & 1876-2015 & $\begin{array}{l}50^{\circ} 04^{\prime} \mathrm{N}, 19^{\circ} 58^{\prime} \mathrm{E} \\
216 \mathrm{~m} \text { a.s.l. }\end{array}$ & $\begin{array}{l}\text { Kożuchowski (1985) for the period 1876-1900, Twardosz (2007) } \\
\text { for the years 1901-2000, Central Database of Historical } \\
\text { Data of IMGW-PIB for the years 2001-2015 }\end{array}$ \\
\hline
\end{tabular}

Key: geographical regions: 1: Baltic coast-Pomerania, 2: Masuria-Podlasie, 3: Greater Poland, 4: Masovia, 5: Silesia, 6: Lesser Poland. * The series for periods 1722-1738 and 1773-1786 were reconstructed based on Reyger's weather chronicle.

R program (R Core Team, 2019) and dplR package (Bunn, 2008) using the smoothing spline option, which reflects trends in the chronology better than other options. The " $n$ year spline" was fixed at two-thirds the wavelength of $n$ years (Cook et al., 1990). The residual version of the chronology was built by pre-whitening, performed by fitting an autoregressive model to the data with AIC model selection (Bunn, 2008). At first the relationships between tree growth and precipitation were checked. We analysed the effect of climate monthly precipitation and temperature on tree-ring widths using the treeclim package (Zang and Biondi, 2015). Analysis of climate growth relationships for monthly data for Torun revealed that precipitation during the vegetation season plays a significant role for both pine and oak. For example, a significant positive correlation was observed for June and July for pine, while for oak a positive correlation was observed for the previous August and current June and a negative correlation for August (Fig. 2). For each site, the climate growth relationships were tested against monthly precipitation and temperature data starting from 1951, and they cover a maximum time span depending on the length of the chronology (Table 6). Because the time span was too short (for example for site 2 when chronology covers the years 1951-1986) for some extended analysis going back to previous months, the common period from previous October to current September was taken into account. The sum of monthly precipitation was also included; the months were selected dependably on the significant correlation of the single months and period selected by daily data analysis.

Next we used daily data for Torun and tree-ring chronologies of pine and oak representing region III. Daily data show more precisely the period of the year which influences tree growth. According to previous findings, the climate growth relationships are comparable at different sites in Poland (Zielski et al., 2010), so we used the relationships between daily data and sites 11 and 13 as a model for the rest of our study sites. The reason for this generalisation was also the limited access to daily data. A period of $90 \mathrm{~d}$ with 
Table 3. Examples of descriptions of extreme droughts (megadroughts) in 15th-17th-century sources.

\begin{tabular}{|c|c|c|c|}
\hline Year & Description & Translation & Source \\
\hline 1473 & $\begin{array}{l}\text { "caumata et penuriam aquarum, adeo ut } \\
\text { perennes aquae verterentur in aridam, et flumina } \\
\text { Poloniae principalia ubique fuerunt permeabilia, } \\
\text { insignis. [...] Fumabant in universis } \\
\text { Poloniae regionibus silvae, borrae, arbusta, saltus, } \\
\text { irremediabili igne, nec ante rescindi flamma poterat, } \\
\text { donec ignis etiam radicem arborum voraret, ex quo } \\
\text { ubique fragor ruentium saltuum audiebatur. } \\
\text { Apum quoque et alveariorum arbores plurimae } \\
\text { deletae, segetes vernales exterminatae siccitate." }\end{array}$ & $\begin{array}{l}\text { "hot weather and a lack of water, to } \\
\text { such an extent that the places where there } \\
\text { had always been water dried up everywhere, } \\
\text { and the main Polish rivers could be crossed } \\
\text { everywhere. [...] Forests, woods, thickets, and } \\
\text { forested hills burnt with fire; there was no way } \\
\text { to put it out, and it was impossible to extinguish } \\
\text { the flame before the fire even devoured the root } \\
\text { of the trees; from here you could hear the clatter } \\
\text { of collapsing thickets. Very numerous bee and } \\
\text { beekeeping trees were destroyed, and many } \\
\text { spring crops were destroyed due to drought." }\end{array}$ & Długosz (2009, vol. 12, p. 336) \\
\hline 1540 & $\begin{array}{l}\text { "fuit in aestate horrenda siccitas adeo, ut silices, } \\
\text { montes et valles quasi igne flagrarent, duravit } \\
\text { haec siccitas usque ad hyemem." }\end{array}$ & $\begin{array}{l}\text { "in the summer there was such a terrible } \\
\text { drought that the rocks, mountains and valleys } \\
\text { were burned down with fire; } \\
\text { this drought lasted until winter." }\end{array}$ & $\begin{array}{l}\text { Archivum vetus et novum ecclesiae } \\
\text { archipresbyteralis Heilsbergensis } \\
(1880, \text { vol. 8, p. 597) }\end{array}$ \\
\hline \multirow[t]{4}{*}{1590} & $\begin{array}{l}\text { "Ist ein sehr heisser truckener Sommer gewesen, } \\
\text { also, dass auch die Landflüsse, als der Bober, } \\
\text { Queiss, Katzbach, Weida, Olau, Lohe, und andere } \\
\text { mehrgänzlich ausgetrucknet. Die Oder ist auch } \\
\text { so klein worden, dass man sie an allen Orten } \\
\text { durchwatten können." }\end{array}$ & $\begin{array}{l}\text { "The summer was so hot [and] dry that regional } \\
\text { rivers like the Bóbr, the Kwisa, the Kaczawa, } \\
\text { the Widawa, the Oława, the Ślęża } \\
\text { [Silesia], and many others dried up } \\
\text { completely. The Odra also became very shallow, } \\
\text { so you could cross it anywhere." }\end{array}$ & Pol, vol. 4, p. 156 \\
\hline & "38 Wochen regnete es nicht. Die Flüsse trockneten aus." & "It did not rain for 38 weeks. The rivers dried up." & Reinhold (1846, p. 143) \\
\hline & "Zacken und andere Flüsse trockneten völlig aus." & "Kamienna and other rivers dried up completely." & Bergemann (1830a, p. 84) \\
\hline & "Der Bober trocknete infolge starker Hitze ganz aus." & "The Bóbr dried up completely due to severe drought." & Bergemann (1830b, vol. 3, p. 85) \\
\hline 1676 & $\begin{array}{l}\text { "Tego roku straszne Panowały Susze, } \\
\text { że zboża wypalało w polach." }\end{array}$ & $\begin{array}{l}\text { "That year a terrible drought took place so } \\
\text { that crops burnt in the fields." }\end{array}$ & $\begin{array}{l}\text { Muzeum Narodowe w Krakowie } \\
\text { rps. MNKr. } 169, \text { p. } 82\end{array}$ \\
\hline 1684 & $\begin{array}{l}\text { "folgete auf Johanni [24.06.] eine grosse } \\
\text { anhaltende Hitze darauf; davon das Erdreich } \\
\text { dermassen dürre wurde, dass das } \\
\text { Sommer-Getreyde, Flachs, und Grass, } \\
\text { gantz zurücke geblieben, das Winter-Korn } \\
\text { an vielen Orten überreiffte, ehe es sich } \\
\text { gehöriger massen in die Ahren kaum angesetzet, } \\
\text { dahero Theurung entstanden" }\end{array}$ & $\begin{array}{l}\text { "The great long-lasting drought arrived on } \\
\text { the St. John's Day [24.06.]; the ground became dry, } \\
\text { the crops became dry; flax and barley grew very } \\
\text { poorly before the proper ear of grain had come out, } \\
\text { which caused very high prices" }\end{array}$ & Gomolcke (1737, p. 32-33) \\
\hline
\end{tabular}

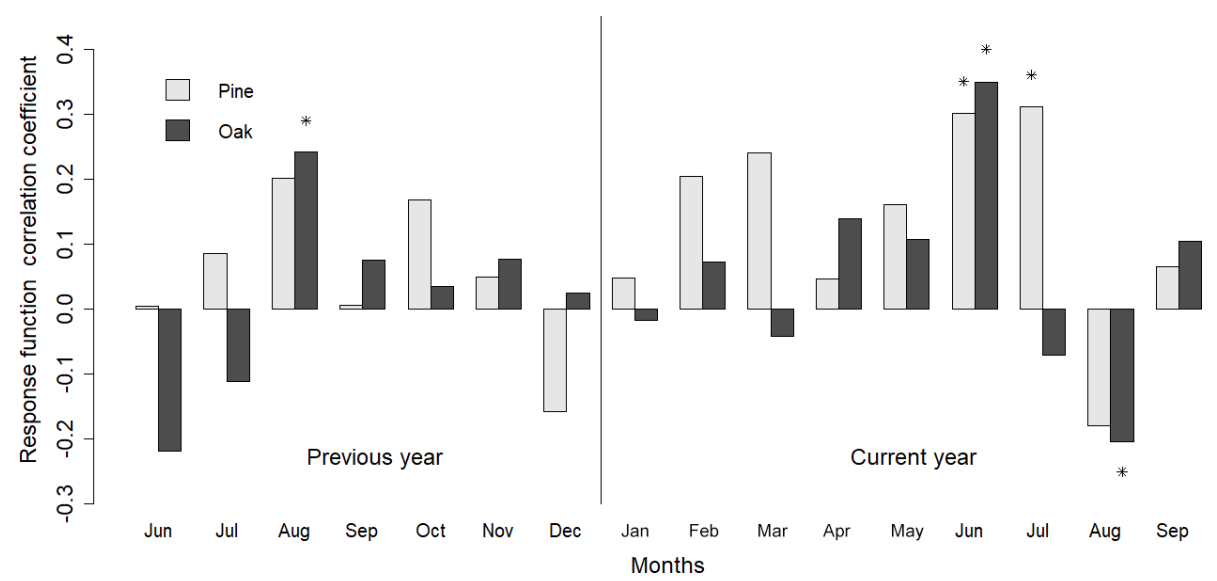

Figure 2. Climate growth relationships between tree rings in pine (grey bars) and oak (black bars) and monthly totals of precipitation. Key: asterisks indicate statistically significant correlation coefficients at the level of 0.05 . Climate data were taken from Torun Meteorological Station. 
Table 4. Examples of descriptions of severe droughts in 15th-17th-century sources.

\begin{tabular}{|c|c|c|c|}
\hline Year & Description & Translation & Source \\
\hline 1456 & $\begin{array}{l}\text { "Fuitque anno eodem precipue circa partes nostras, } \\
\text { ubi plures sunt agri sabulosi et argillosi, } \\
\text { post festa paschalia siccitas magna et usque } \\
\text { ad messem continuata. Messis autem tante } \\
\text { humiditatis et instabilitatis," }\end{array}$ & $\begin{array}{l}\text { "And that year there was an exceptionally great } \\
\text { drought in our area, where there are numerous } \\
\text { sandy and loamy soils; it occurred after } \\
\text { the Easter holidays and lasted until the harvest. } \\
\text { In the harvest period it [the weather] } \\
\text { was so wet and unstable" }\end{array}$ & $\begin{array}{l}\text { Catalogus abbatum } \\
\text { Saganensium (1835, p. 340) }\end{array}$ \\
\hline 1532 & $\begin{array}{l}\text { "Ein dürrer Sommer. Es regnete in } \\
\text { sieben Wochen nicht. Das Getreide und } \\
\text { die Weide verdorrete auf den Hügeln ganz aus. } \\
\text { In etlichen Dörfern war kein gar Wasser. } \\
\text { Auf dem Lande konnte man nicht mahlen. } \\
\text { Zu 10. 12. 18. Meilen musste man zur Mühle } \\
\text { führen. Die Olau trocknete und dorrete } \\
\text { auch aus, und hatte kein Wasser bis } \\
\text { auf Bartholomei [24.08]." }\end{array}$ & $\begin{array}{l}\text { "Dry summer. It did not rain for seven weeks. } \\
\text { The grain and grass on the hillsides dried up. } \\
\text { In some places there was almost no water. } \\
\text { In the countryside, it was impossible to grind grain. } \\
\text { One needed to go 10,12,18 miles to reach mills. } \\
\text { The Oława River dried up [Silesia, auth. suppl.]. } \\
\text { and there was no water in it until } \\
\text { the Saint Bartholomew's Day [August 24]." }\end{array}$ & Pol (1819, vol. 3, p. 72) \\
\hline 1665 & $\begin{array}{l}\text { "Der Sommer des Jahres } 1665 \text { wird als ungemein } \\
\text { heiss angegehen, und soll es die ganzen } \\
\text { Hundstage [10.07.-20.08.] hindurch auch } \\
\text { nicht einmal geregnet haben." }\end{array}$ & $\begin{array}{l}\text { "The summer of } 1665 \text { was incredibly hot; } \\
\text { not even once did it rain - } \\
\text { so-called 'Dog Days'." }\end{array}$ & Wernicke $(1842$, p. 321) \\
\hline
\end{tabular}

Table 5. Descriptions of moderate droughts in 15th-17th-century sources.

\begin{tabular}{llll}
\hline Year & Description & Translation & Source \\
\hline 1461 & $\begin{array}{l}\text { "Eodem anno fuit estas calidissima et } \\
\text { fluvius Odere valde modicus, similiter } \\
\text { et alii fluvii." }\end{array}$ & $\begin{array}{l}\text { "That year the summer was the hottest and } \\
\text { the water level of the Odra river fell, } \\
\text { as did other rivers." }\end{array}$ & $\begin{array}{l}\text { Sigismundi Rosiczii chronica } \\
(1883, \text { p. 78) }\end{array}$ \\
\hline 1552 & $\begin{array}{l}\text { "Den 5 Junii [...] nach der Vesper und } \\
\text { grosser Dürre kam ein gewünschter } \\
\text { Regen, aber mit grossem Wetter." }\end{array}$ & $\begin{array}{l}\text { "On June 5 [...] after the evening and } \\
\text { after a great drought, came the desired } \\
\text { rain with a great storm." }\end{array}$ & Pol (1819, vol. 3, p. 158) \\
\hline 1661 & $\begin{array}{l}\text { Es folgte aber ein dürrer Sommer." } \\
\text { "However, a dry summer came." }\end{array}$ & Happel (1690, p. 148) \\
\hline
\end{tabular}

the 1-year lag for the years 1947-2015 was used to find the significant relationships between the daily precipitation data and indexes of tree rings. For this purpose, we used the dendroTools package (Jevšenak and Levanič, 2018). The optimal window of days was revealed to be from 6 May to 3 August for pine with maximal correlation coefficient 0.435 and from 21 April to 19 July for oak with maximal correlation coefficient 0.305 . The sums of daily precipitation for these periods were summed and correlated with indexed growth in years of growth reduction (narrow rings) and growth recovery (wide rings). The correlation coefficient is $0.79(p<0.05)$ for pine and $0.65(p<0.05)$ for oak. Next, the same summed daily precipitations for the selected periods were correlated with the remaining tree-ring indexes (after exclusion of wide- and narrow-ring indexes). The correlation coefficients are 0.40 for pine and 0.16 for oak.

To determine the pointer years we used the dplR package (Bunn, 2008). The minimum absolute relative radial growth variation, above which the growth change from year $t-1$ to $t$ is considered significant, was 10 . Any year in which more than $95 \%$ of trees per site displayed significant relative radial growth variations above 10 was qualified as "extreme reduction"; "great reduction" was determined as between $85 \%$ $95 \%$ of trees; and "moderate reduction" was between $75 \%$ and $85 \%$.

\subsection{Instrumental data}

As shown in Table 2, for the analysis of droughts in the instrumental period, eight long-term series of monthly totals of precipitation have been used. All these precipitation series were checked for completeness. The few data gaps in the analysed series were completed using homogenised precipitation series from the nearest stations. For this purpose, a simple method of constant quotients was utilised (Pruchnicki, 1987). However, due to the lack of available reference series, such a procedure was not used to fill data for the period 1880-1884 for Orzysz. Homogenisation of all the used precipitation series was checked using the AnClim software (Štěpánek et al., 2009). 
Table 6. Climate growth relationships for analysed sites. Only highest correlation coefficients are presented with a level of significance $p<0.05$.

\begin{tabular}{|c|c|c|c|c|}
\hline $\begin{array}{l}\text { Site } \\
\text { number }\end{array}$ & $\begin{array}{l}\text { Analysed } \\
\text { period }\end{array}$ & $\begin{array}{l}\text { Highest Pearson } \\
\text { correlation } \\
\text { coefficient }\end{array}$ & $\begin{array}{l}\text { Months with highest } \\
\text { correlation coefficient }\end{array}$ & $\begin{array}{l}\text { Meteorological } \\
\text { station }\end{array}$ \\
\hline \multicolumn{5}{|c|}{ Region I (Baltic province) } \\
\hline Site 1 & $1951-1987$ & 0.378 & Sum of precipitation from May to June & Koszalin \\
\hline Site 2 & $1951-1986$ & 0.296 (not significant) & Sum of precipitation from June to July & Gdańsk \\
\hline Site 3 & $1951-1987$ & 0.565 & Sum of precipitation from June to August & Świnoujście \\
\hline Site 4 & $1175-1396$ & No climate data & No climate data & No climate data \\
\hline Site 5 & $1951-1986$ & 0.456 & Sum of precipitation from June to July & Koszalin \\
\hline \multicolumn{5}{|c|}{ Region II (Masuria-Podlasie province) } \\
\hline Site 6 & $1951-1987$ & 0.589 & Temperature current May & Suwałki \\
\hline Site 7 & $1951-1987$ & 0.50 & Sum of precipitation from June to July & Suwałki \\
\hline Site 8 & $1951-1985$ & 0.285 & Sum of precipitation from July to August & Białystok \\
\hline \multicolumn{5}{|c|}{ Region III (Greater Poland-Pomerania province) } \\
\hline Site 9 & $1951-1987$ & 0.485 & Sum of precipitation from May to July & Poznan \\
\hline Site 10 & $1951-1987$ & -0.322 & Temperature, previous December & Gorzów Wielkopolski \\
\hline Site 11 & $1951-2015$ & $0.334,-0.335$ & $\begin{array}{l}\text { Sum of precipitation from May to June, } \\
\text { temperature in June }\end{array}$ & Toruń \\
\hline Site 12 & $1249-1490$ & No climate data & No climate data & No climate data \\
\hline Site 13 & $1951-2015$ & 0.443 & Sum of precipitation from May to July & Toruń \\
\hline Site 14 & $1100-1468$ & No climate data & No climate data & No climate data \\
\hline \multicolumn{5}{|c|}{ Region IV (Masovia-Podlasie province) } \\
\hline Site 15 & $1951-1985$ & -0.316 & Temperature, previous December & Warszawa \\
\hline \multicolumn{5}{|c|}{ Region V (Silesia province) } \\
\hline Site 16 & $1886-1984$ & $\begin{array}{l}>0.4 \text { precipitation data } \\
\text { not presented due to lower } \\
\text { statistical significance }\end{array}$ & $\begin{array}{l}\text { Temperature of February and } \\
\text { March for pine }\end{array}$ & $\begin{array}{l}\text { Opole, Wrocław, } \\
\text { Katowice and } \\
\text { Racibórz }\end{array}$ \\
\hline Site 17 & $1951-1987$ & 0.376 & Sum of precipitation from May to June & Wrocław \\
\hline Site 18 & $1568-2010$ & Only pointer years were analysed & & \\
\hline \multicolumn{5}{|c|}{ Region VI (Lesser Poland province) } \\
\hline Site 19 & $1915-1986$ & 0.324 (not significant) & Temperature in February & Kraków \\
\hline Site 20 & $1951-1989$ & $0.314,-0.323$ & $\begin{array}{l}\text { Sum of precipitation from May to July, } \\
\text { temperature in June }\end{array}$ & Lublin and Radawiec \\
\hline Site 21 & 1881-1999 & $>0.4$ & Temperature in March & Kraków \\
\hline Site 22 & $1881-1999$ & $>0.4$ & Temperature in February & Kraków \\
\hline
\end{tabular}

On the basis of the completed series of atmospheric precipitation, the possibility of obtaining a synthetic precipitation index for the whole country was tested. A similar method was adopted in Brázdil et al. (2007) to determine drought indices in the Czech Republic for the period 1881-2006. In Poland, Kożuchowski (1985) presented a 100year series of average areal annual atmospheric precipitation for 1881-1980 (his Table 3) calculated from data from 12 meteorological stations using precipitation regression equations relative to altitude above sea level. Miętus (1996), in turn, presented mean areal precipitation for the coastal area. For the analysis, we took 30-year moving correlation coefficients $(r)$ for monthly totals of precipitation counted for the period 1901-2000. All correlation coefficients were statistically significant $(p<0.05)$ with values varying from 0.46 to 0.71 (see Table 7, upper part). Only the Kraków series had a 
significantly lower value of $r$ (the highest value of 0.33 described the relationship between Kraków and Wrocław). For annual precipitation totals in the period 1951-2000, Kożuchowski and Żmudzka (2003) obtained only slightly higher values of correlation coefficients, varying from 0.6 to 0.8 . Unsatisfactory results of $r$, particularly related to the series for Kraków, suggested that we should not construct monthly precipitation series for the whole of Poland. It seems that the number of long-term precipitation series is probably relatively too small for a country of such an area $\left(312679 \mathrm{~km}^{2}\right)$. Further analysis was thus carried out on regions delimited by a landscape criterion, though this excludes mountains, whose atmospheric precipitation is spatially and temporally far more variable (Kożuchowski, 1985).

The aim of the analysis of instrumental series was to calculate the number, length, and category of droughts in the area of Poland since 1722, i.e. for almost 300 years. The Standardised Precipitation Index (SPI: McKee et al., 1993) was calculated from monthly precipitation totals to explore the occurrence of droughts in the analysed locations (Table 2). This index is one of the simplest methods used to identify meteorological droughts, since it uses only monthly totals of precipitation and is therefore widely used in the literature. Osuch et al. (2016) state that the SPI is used for both research and operational purposes in over 60 countries. The SPI is also most popularly used in Poland (e.g. Łabędzki, 2007; Kalbarczyk, 2010; Bąk et al., 2012; Bartczak et al., 2014; Osuch et al., 2016; Bąk and Kubiak-Wójcicka, 2017). What is more, the SPI is used also by two institutes mentioned in Sect. 1 (IMGW-PIB and the Institute of Technology and Life Sciences, ITP) and also by the Institute of Soil Science and Plant Cultivation, which is responsible for agricultural drought monitoring in Poland (for more details see Łabędzki and Bąk, 2014). Hence our decision to also use this index in our work.

The program SPI Generator (National Drought Mitigation Center, University of Nebraska) was used to perform this analysis. SPI was initially calculated for 1-, 3-, 6-, 12-, and 24-month timescales. Further analysis was, however, done using SPI calculated only for 1-, 3-, and 24-month timescales. All of them represent meteorological droughts, from short-term to long-term droughts. The last two (SPI3 and SPI24) can also be used as a good proxy for agricultural and hydrological droughts, respectively. For climate conditions in Poland, it was shown that there exists a strong spatial relationship of SPI values (Table 7, lower part). Significant empirical relations were also found between SPI and pure agricultural and hydrological indices. Łabędzki et al. (2008) found high correlation coefficients $(|r|>0.7)$ between SPI and some agricultural indices such as crop drought index $(\mathrm{CDI})$, water deficit $(\mathrm{N})$, and relative duration of soil moisture deficit $\left(t_{\mathrm{def}}\right)$. On the other hand, a much weaker relation $(r<0.5)$ was found between SPI24 and hydrological droughts estimated based on SWI-24 (24-month Standardised Water-level Index) for the Wisła river in Toruń by Bąk and Kubiak-Wójcicka (2017). According to them, this relation was reduced by the influence of external factors (the hydropower plant in Włocławek located in middle part of the river, major groundwater basin), and climate factors appearing in the upper and middle parts of the river basin.

To identify droughts (dry months), the criterion proposed by McKee et al. (1993) and modified for Polish climate conditions by Łabędzki (2007) was used. Droughts were divided into three categories based on SPI values: moderate $(-0.50$ to -1.49$)$, severe $(-1.50$ to -1.99$)$, and extreme $(\leq-2.00)$ droughts. Methods that identify multi-month droughts using the SPI calculated for different, rigidly defined numbers of consecutive months (3, 6, 12 or 24) simplify the analysis, especially in terms of drought duration and calculating the cumulative intensity of the whole phenomenon. Therefore, in this work, we have adopted the following criteria to identify droughts and determine their duration. Firstly, instances of an SPI1 value within any of the above ranges for only a single month were considered irrelevant. Secondly, a drought was considered to be at least two consecutive months during which the SPI1 value was $\leq-0.50$. Thus identified, a drought was determined both in terms of duration and by category. Thirdly, drought category was determined by the dry month of lowest SPI1 value. A drought was thus considered extreme if the SPI1 value for at least one of the drought months was $\leq-2.00$. If the SPI1 of the driest month within a particular instance of drought was between -1.50 and -1.99 , the drought was determined to be severe. The remaining droughts were qualified as moderate. The number of droughts was determined for years and for climatological seasons. A drought's final month determined its season.

Drought is a widely occurring phenomenon, but its frequency is extremely limited within particular long-term periods. For this reason, it was decided to group numbers of droughts into longer periods. For a fuller comparison of drought occurrence identified on the basis of dendrochronological data (narrow rings), we used instrumental data to calculate the number and duration of droughts within 10-year periods, starting from the slightly shorter period $1722-1730$, through full decades, to the 5-year period 2011-2015. Next, we also summed the number of droughts by a 50 -year period, also determining seasons in this case, just as we did when analysing the documentary data.

For the purpose of comparison of SPI1 values (meteorological droughts) against historical indices $(-1,-2$, and -3$)$, the following assumptions were established: the index -1 was attributed to SPI1 values ranging from -0.50 to -1.49 ; -2 for the range -1.50 to -1.99 ; and -3 for SPI $1 \leq-2.00$. Frequency of occurrence of meteorological droughts for the instrumental period was calculated for standard meteorological seasons (December-February, March-May, etc.) as well as for May-July. This allowed for comparison of the occurrence of droughts against their statistics available in documentary evidence (seasons) and dendrochronological data (May-July). The last period was added because for this time 
Table 7. Correlation coefficients between monthly totals of atmospheric precipitation (upper part of table) and SPI1 (lower part of table) in the area of Poland calculated based on data from the period 1901-2000.

\begin{tabular}{lrrrrrrrc}
\hline Station & Toruń & Koszalin & Gdańsk & Orzysz-Mikołajki & Poznań & Warszawa & Żagań-Wrocław & Kraków \\
\hline Toruń & & 0.56 & 0.67 & 0.62 & 0.69 & 0.62 & 0.61 & 0.29 \\
Koszalin & 0.56 & & 0.71 & 0.55 & 0.55 & 0.52 & 0.46 & 0.20 \\
Gdańsk & 0.62 & 0.69 & & 0.66 & 0.58 & 0.61 & 0.55 & 0.26 \\
Orzysz-Mikołajki & 0.55 & 0.53 & 0.60 & & 0.55 & 0.71 & 0.54 & 0.31 \\
Poznań & 0.66 & 0.57 & 0.55 & 0.49 & & 0.58 & 0.68 & 0.25 \\
Warszawa & 0.58 & 0.48 & 0.52 & 0.63 & 0.53 & & 0.61 & 0.28 \\
Żagań-Wrocław & 0.56 & 0.44 & 0.47 & 0.45 & 0.64 & 0.53 & & 0.33 \\
Kraków & 0.00 & -0.03 & -0.03 & -0.03 & -0.03 & -0.02 & 0.00 & \\
\hline
\end{tabular}

Values statistically significant at the level of $p<0.05$ are shown in italic.

a significant influence of precipitation on tree-ring widths in Poland was found (see Sect. 3.2). It was revealed that most of the growth reduction (negative pointer years) was related to the occurrence of drought. Thus, years with extreme, great, and moderate tree-growth reductions can roughly, and with a large probability, indicate the occurrence of extreme, severe, and moderate droughts, respectively. In the case of documentary data such droughts were described using indices $-3,-2$, and -1 .

As mentioned in Sect. 3.1, information about drought in historical times is rather heavily underestimated, in particular in the case of moderate droughts; therefore, documentary data that identified droughts of categories -2 and -3 have frequently been used for the purpose of comparison against other sources. Such an approach also increases the probability that identified droughts occurred in large parts of Poland. In addition, to be sure that they were caused only by climate, the assumption of their occurrence in a minimum of two geographical regions was usually also utilised. On the other hand, for comparison of droughts delimited using dendrochronological and instrumental data, all categories of them were used.

The number of months $N_{i}$ in each class of drought intensity (moderate, severe, and extreme) was computed for the 1-, 3-, and 24-month timescales. Then the number of droughts per century was calculated according to the following formula proposed by Łabędzki (2007):

$N_{i, 100}=\frac{N_{i}}{i \cdot n} \cdot 100$,

where $N_{i, 100}$ is the number of droughts for a timescale $i$ in 100 years, $N_{i}$ is the number of months with droughts for a timescale $i$ in the $n$-year set, $i$ is the timescale $(1,3$, 24 months), and $n$ is the number of years in the particular study data set.

\section{Results}

The climatic conditions of Poland have been characterised many times by different authors such as Paszyński and
Niedźwiedź (1991), Woś (1999), and Lorenc (2005). For many years, the Polish National Meteorological and Hydrological Service (IMGW-PIB) has been presenting the fruitful results of their monitoring (http://klimat.pogodynka.pl/, last access: 4 March 2020), allowing analyses and assessments to be made.

The climate of Poland is in general temperate. Due to its location in the central part of the continent, being considerably affected by oceanic features in the western part of the country and a pronounced continental impact in the east, the area of Poland is diverse in terms of climatic conditions. An important geographic feature of Poland is the latitudinal course of its natural landscape types - from its sea coast in the north to its lake lands, lowlands, uplands, and mountains located southward.

The mean annual air temperature in particular regions of the country varies from almost $7^{\circ} \mathrm{C}$ to nearly $10^{\circ} \mathrm{C}$ (as for the period 1981-2010) with lowest temperatures in January (from -3.5 to $0.5^{\circ} \mathrm{C}$ ) and highest temperatures in July (from 16.5 to $19.5^{\circ} \mathrm{C}$ ) (IMGW 2020). The whole country is experiencing a systematic considerable increase in air temperature with rates of increase of $0.3{ }^{\circ} \mathrm{C}$ every 10 years, occurring since the second half of the 20th century. The largest increases have taken place in northern and western parts of Poland. In 2019 , mean annual air temperature reached $10^{\circ} \mathrm{C}$, translating into the warmest year in Poland since the beginning of instrumental measurements of air temperature. Annual precipitation ranges from $450 \mathrm{~mm}$ in the central belt via $700 \mathrm{~mm}$ in the uplands to $1500-1700 \mathrm{~mm}$ in the highest mountain ranges in southern Poland (IMGW-PIB, 2020). February is the driest month in Poland and July is the month when the highest monthly precipitation totals occur. During the last number of decades, symptoms of the systematic drying of climate in Poland has been observed. Westerly and south-westerly winds predominate and only in northern coastal parts of the country is there a considerable amount of north-westerly winds. 


\subsection{Droughts in Poland based on documentary data}

It seems that droughts were not very frequent in Poland. In particular regions (including droughts presented in sources as nationwide, and therefore also noticeable in individual regions) in total from 33 to 71 droughts were recorded between 1451 and the end of the 18th century (Fig. 3). Most of those were recorded in Pomerania and Silesia and the least were recorded in Greater Poland, Masuria, and Mazovia (Figs. 3 and 4). This is undoubtedly not a reflection of the frequency of droughts in individual regions, but a consequence of the sources preserved for each region. Without a shadow of doubt, the richest and most accurate sources come from two regions: Pomerania (especially from big cities like Gdańsk, Toruń, and Elbląg) and Silesia. It very often happens that one drought is described in many sources from the region; moreover, it is confirmed by records referring to the entire territory of Poland. A drought described in this way can be analysed more accurately. The sources from Greater Poland, Mazovia, and Masuria are definitely poorer. Consequently, it is probable that the number of droughts in these regions was actually higher and close to the number of droughts in Silesia or Pomerania.

Information that refers to the same year and comes from different regions confirms a larger territorial range of drought. This does not mean, however, in cases where such information was preserved only for one of the regions, other areas were not affected by drought. This lack of reports may have resulted from the lack of appropriate sources and not from the fact that there was no drought in a given region. These numbers undoubtedly depend on the surviving sources and reflect part of the actual state of affairs. In order to partially compensate for these source deficiencies, it was assumed that the records referring to drought in the whole country refer simultaneously to each of the six identified regions.

We also calculated the frequency of all droughts occurring (Fig. 5). In the chronological order in the periods of 50 years, the number of extreme droughts $(-3)$ never exceeded five; in the first half of the 16th century only the drought of 1540 was recognised as such, while in the first half of the 17th century extreme droughts were completely absent (Fig. 5). It seems that extreme droughts, whose total number in the period 1451-1800 was 17 , were regularly recorded in sources, and this information is quite reliable.

The number of severe droughts $(-2)$ was usually between four and nine in particular periods of 50 years. Many more droughts belonging to this category were recorded in the second half of the 17th century and in the second half of the 18th century; their numbers were respectively 14 and 13 (Fig. 5).

However, the total frequency of extreme $(-3)$ and severe $(-2)$ droughts amounted to 80 and ranged from 4 to 12 in particular 50-year periods, except for the second half of the 17 th century and the second half of the 18th century, when there occurred as many as 18 and 16 droughts, respectively

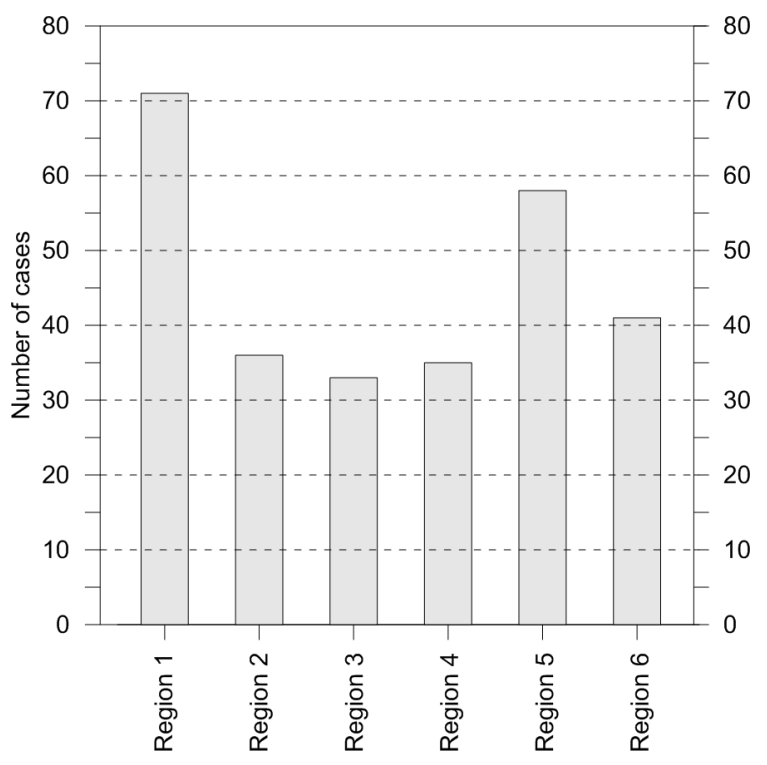

Figure 3. Number of years with droughts in six geographical regions of Poland (including information related to the whole country) 1451-1800. See Table 2 or Fig. 4 for the names of regions.

(Fig. 5). The increase in the number of identified droughts in the second half of the 17th century was certainly due to the availability of detailed weather records from the period 1656-1685 taken from the memoirs of Jan Antoni Chrapowicki (Nowosad et al., 2007). However, the minimum number of droughts (only four) took place in the first half of the 17th century (Fig. 5), for which, in turn, we recorded significant losses in the sources.

The number of moderate droughts $(-1)$ varied in all 50year periods from 3 to 6 , except for the second half of the 18th century, when there were as many as 11 droughts belonging to this category recorded (Fig. 5). A larger number of such droughts starting from the beginning of the 18th century undoubtedly results from regional sources being more accurate. In this century, many historical sources were created; they now allow for a fairly accurate reconstruction of the weather conditions, including the appearance of smaller droughts and prolonged shortages of rainfall.

Spring (31) and summer (37) droughts prevailed among the recorded droughts. Also, droughts in spring-summer were often mentioned (22) but much less frequently in summer and autumn (4). Rare were droughts that occurred only in autumn (4). Winter droughts were reported only in three different years. In the case of many reports mentioning "a drought occurring this year" it is difficult to decide what the time of its occurrence was.

Nevertheless, the findings should be treated with some caution. The specificity of the chronicle's narrative was that weather phenomena were recorded in the case of their extreme rare character or because of their consequences for human existence. Droughts undoubtedly posed a serious threat 


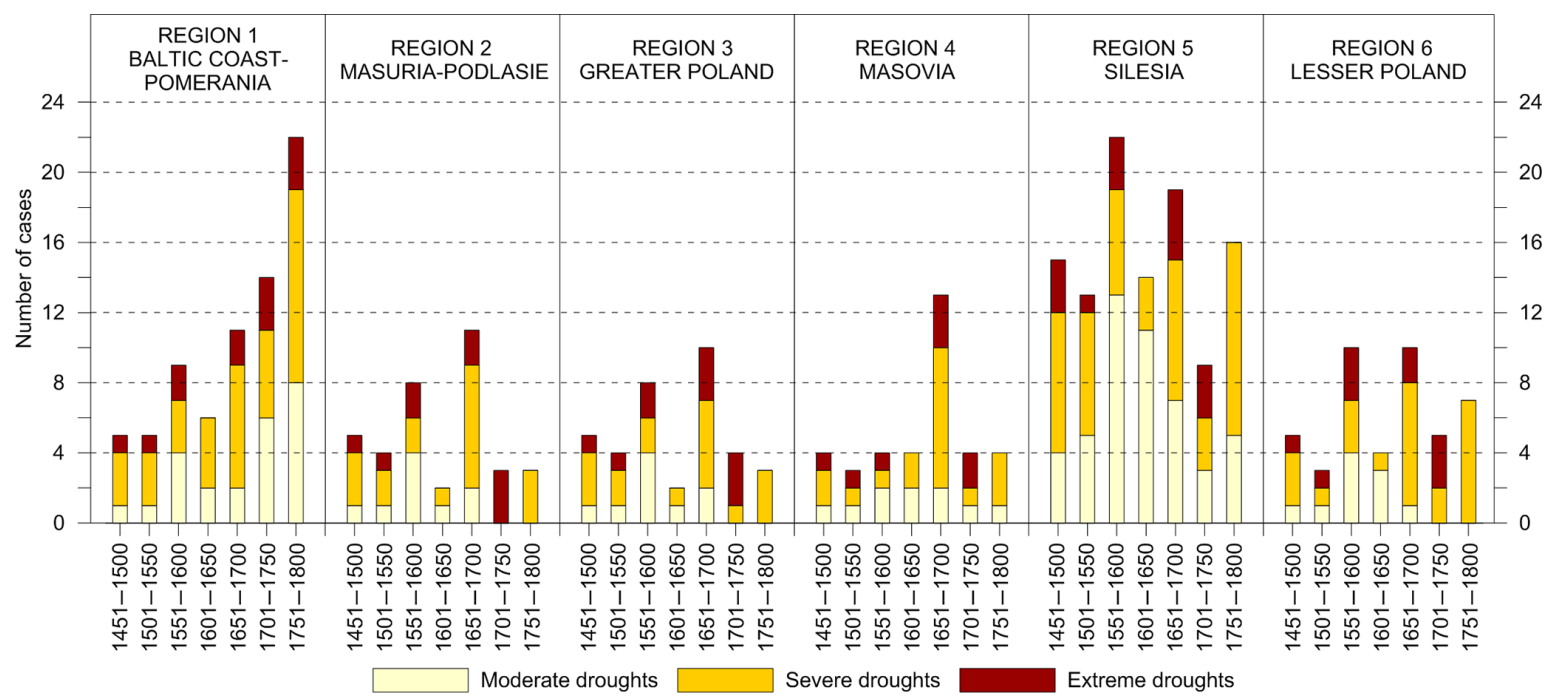

Figure 4. Frequency of occurrence of three categories of droughts in six distinguished geographical regions in Poland in 50-year periods, 1451-1800.

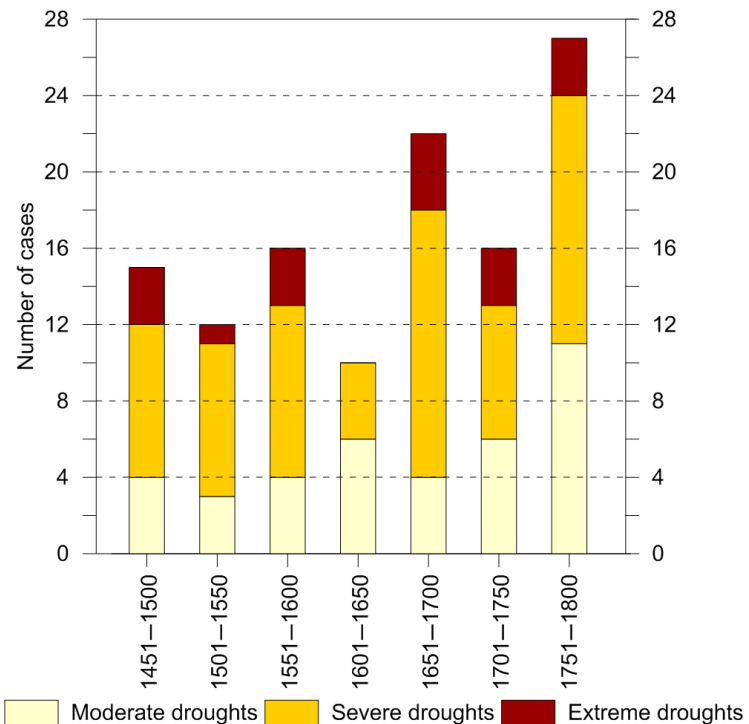

Figure 5. Frequency of occurrence of three categories of droughts in Poland in 50-year periods, 1451-1800.

to crops during periods of plant growth - above all in spring and summer. In the case of winters, the lack of snowfall could hardly be perceived as a manifestation of drought.

\subsection{Droughts in Poland based on dendrochronological data}

Twenty-two local chronologies of trees (pine, oak, and fir) from Poland were taken into account for detecting negative pointer years, showing narrow rings. In a year in which we have narrow rings at more than one site, we count this pointer year as a "multiple observation" year, whereas in a year with only one observation, at one site, we call it a year "without multiple observation". In total, 758 pointer years with multiple observations were detected and 432 years without multiple observations. There are 237 multiple observation years of extreme reduction, 122 of great reduction, 252 of moderate reduction, and 147 negative pointer years from the literature (Opała and Mendecki, 2014; Opała, 2015; Szychowska-Krapiec, 2010) (Fig. 6). The number of pointer years in selected 50-year periods varies (Fig. 7). At least 30 pointer years were noted within the years $1401-1450$ and within each of the 50-year intervals from 1701 to 1950 . The evidently smallest number of negative pointer years occurred in the first 150 years (Fig. 7). In the years 996-1000, drought did not occur, and therefore this period was omitted in Figs. 6 and 7. However, the small number of pointer years from 996 to 1200 may be related to the low number of samples. This period is called as Medieval Climate Anomaly and reconstruction for northern-central Europe revealed considerably drier conditions for these years (Scharnweber et al., 2019). The number of chronologies varies and depends on region. More chronologies in the last 300 years result from existing old trees. It also led to the detection of more pointer years. According to Neuwirth et al. (2007), during extreme climatic conditions trees react in the same way, but during years of less pronounced weather conditions regional differences in growth reactions increase. Narrow rings observed in the same year in trees from different regions suggests extreme climatic conditions.

\subsection{Droughts in Poland based on instrumental data}

Instrumental observations of precipitation in Poland are among the longest-standing observations in the world (Filipiak, 2007). As shown in Table 2, they are available since 

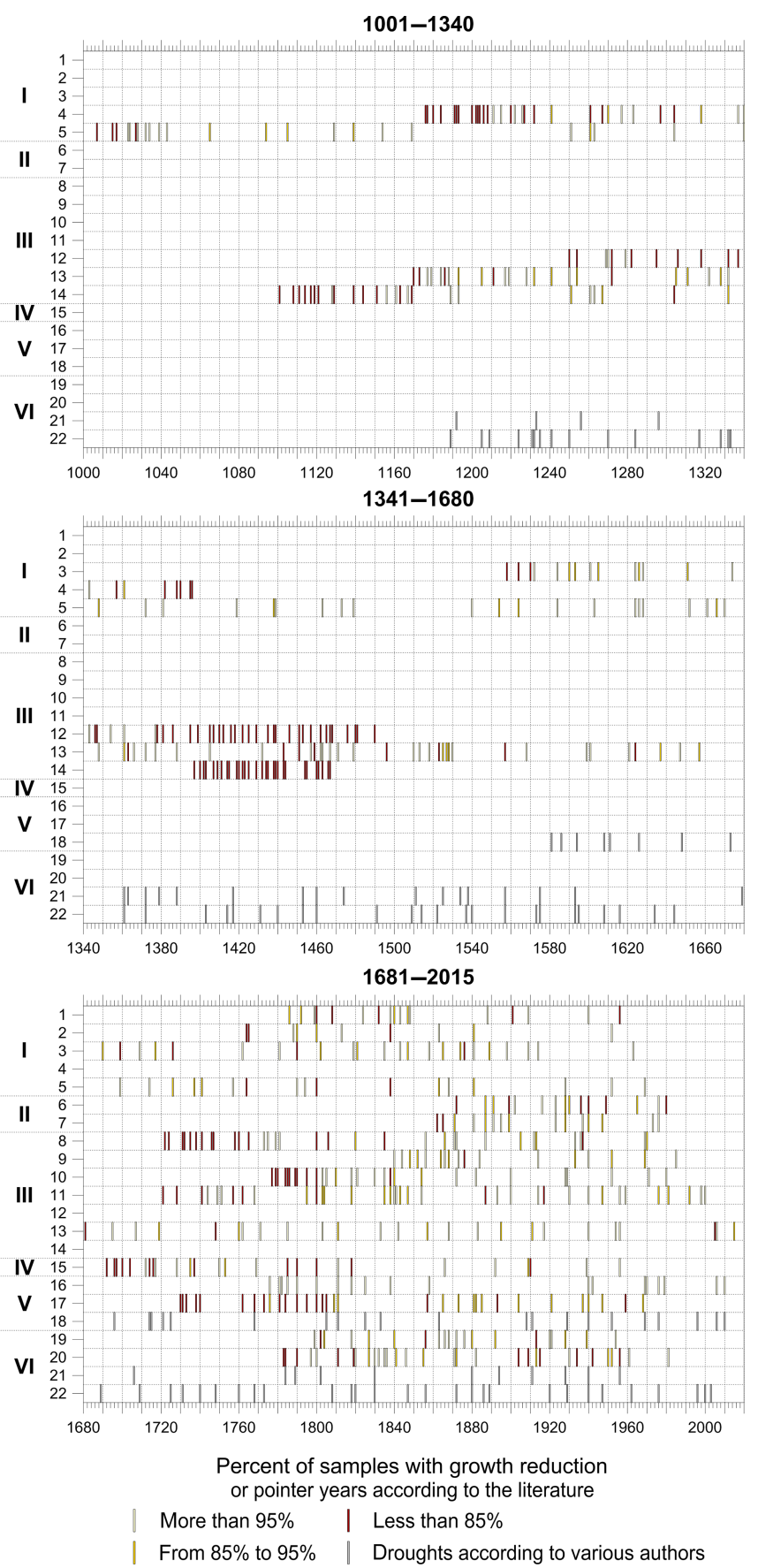

Figure 6. Pointer years in Poland (1001-2015).

1722. In Fig. 8 we present the SPI calculated for eight sites in Poland for 1-, 3-, and 24-month timescales. The values of SPI3 and SPI24 were filtered by 10-element and 30-element low-pass Gauss filters, respectively, in order to more clearly distinguish long-term dry periods. The analysis of Fig. 8 reveals that the occurrence of droughts in different areas of Poland shows both similarities and discrepancies. It is very clear that in northern and central Poland, a long-term (24month duration, red line) and extreme drought occurred at

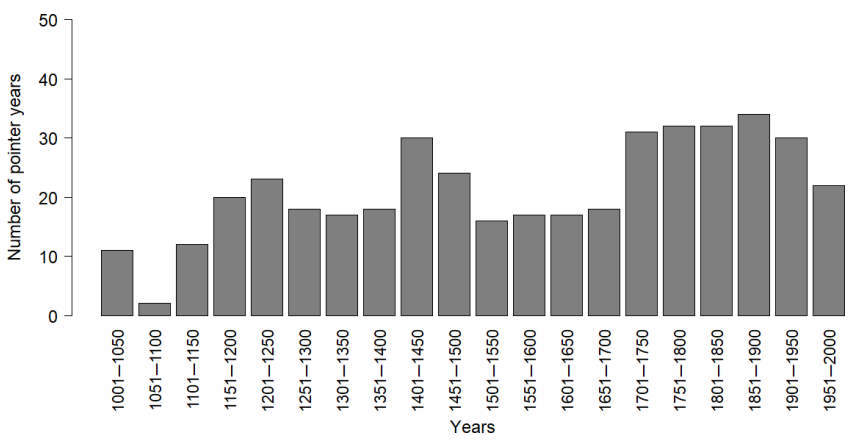

Figure 7. Number of negative pointer years (without multiple observation - i.e. narrow rings in 1976 were observed on six samples but are treated as one pointer year) in Poland in 50-year periods (1001-2000).

the threshold of the 1850s/60s. Almost 100 years later (at the threshold of the 1940s/50s) such a strong drought was present across the entire area of Poland (Fig. 8). Except for Kraków, and also Gdańsk in the last few years, severe droughts have not been observable at the turn of the 21 st century. In Silesia, a very dry period occurred for almost the entire first half of the 19th century, and then significantly less severe droughts occurred only in the 1950s and 1990s. For the 18th century, we mainly have information for Gdańsk. Figure 8 shows that dry periods (moderate droughts) occurred here only at the threshold of the 1750s/60s and in the mid-1770s. The most extreme droughts in different parts of Poland occurred in different times. For example, in Gdańsk at the threshold of the 1910s/20s, in Koszalin and OrzyszMikołajki in the 1850s, in Torun in the 1910s, in Poznan in the 1980s, and in Kraków in the 1980s and 1990s (Fig. 8).

Trend coefficients calculated for three types of SPI (SPI1, SPI3, and SPI24) are very small and not statistically significant in all study regions. This means that the long-term frequency of droughts in Poland has been stable for the last two or three centuries.

The number of moderate, severe, extreme, and all-category droughts (see Sect. 3 for definitions) in 10-year periods calculated from the Polish instrumental series (oriented from north to south) in the period 1722-2015 is presented in Fig. 9. In the period 1876-2015, for which complete series of SPI are available for all study sites, the number of all-category droughts (Fig. 9d) varies mainly in the ranges 3-4 and 8-12 per decade. Below the lower threshold of this range we must mention the occurrence of only two droughts in the decade 2001-2010 in Warszawa. On the other hand, this range of frequency was exceeded in only three decades. The greatest 10 -year number of all-category droughts (14) in the study period was noted in Gdańsk in the decade 1881-1890. In another two decades (1951-1960 and 1991-2000) 13 droughts occurred in Toruń and Kraków, respectively (Fig. 9d). Two decades 1851-1860 and 1861-1870 were very dry in Poland, in particular in its northern and western parts, and the num- 


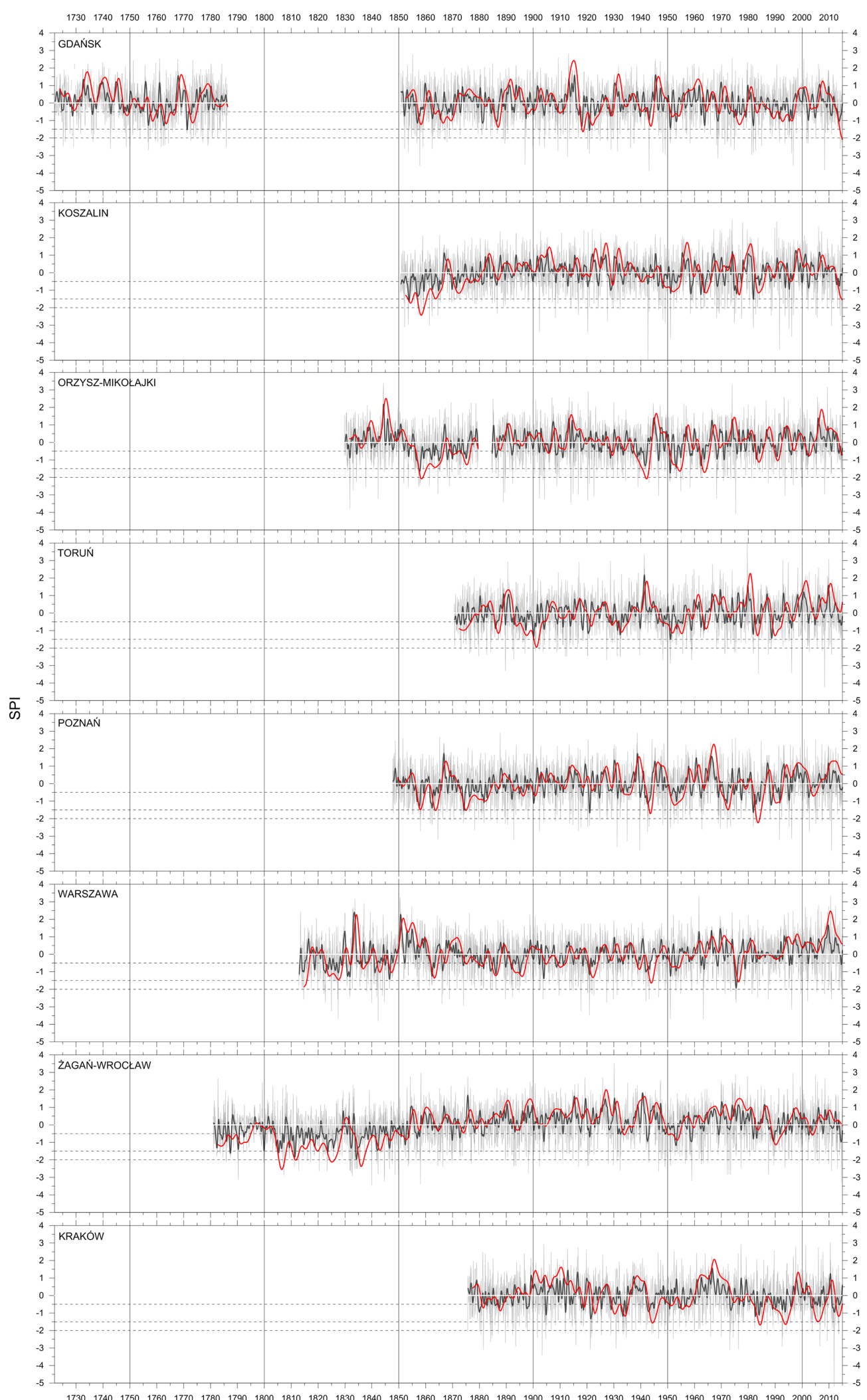

Figure 8. Variability in SPI: 1-month (grey curve), 3-month (black curve), and 24-month (red curve) variabilities calculated from the Polish instrumental series listed in Table 2 (oriented from north to south) in the period 1722-2015. SPI3 and SPI24 were filtered by 10 -element and 30-element low-pass Gauss filters, respectively. Dashed lines indicate thresholds taken for distinguishing drought categories (see Sect. 3 ). 
ber of droughts varied between 6 and 10 per decade. For pre1850 , the information about drought occurrence is significantly sparser, but it can be stated that in both areas for which data exist (Silesia and Masovia) the number of droughts in the first half of the 19th century (8-14 per decade) was higher than in the rest of the study period. The contrast is particularly great for Silesia (see also Fig. 8). The number of droughts occurring in the 18th century varied from 4 to $8-9$ per decade and was typical as in the rest of the study period (Fig. 9).

In line with expectations, moderate droughts evidently dominate, usually with a frequency of 2-8 per decade (Fig. 9a), then severe (Fig. 9b) and extreme (Fig. 9c) droughts with typical frequencies not being much different at 1-4 and 1-3 per decade, respectively. In terms of these drought characteristics (Fig. 9), as with the characteristics described by SPI1, SPI3, and SPI24 (see Fig. 8), no long-term trends are observable in Poland for the last two or three centuries.

For comparison against the number of droughts delimited using documentary evidence, 50-year frequencies of the three categories of droughts were calculated for climatological seasons (Fig. 10). It comes as little surprise that the frequency of all-category droughts was greatest in winter. Other seasons show more or less similar frequencies. In winter, droughts evidently dominated in the study period in the second half of the 19th century, this is particularly well seen in the case of severe droughts, and slightly less so for moderate droughts, which were also quite frequent in the first half of the 20th century. Extreme droughts in winter do not show any significant changes over time, but it should be emphasised here that they were slightly more frequent in 1951-2000 than in 1851-1900. Moreover, in addition to winter droughts, it should be pointed out that the deficiency in precipitation during this season is usually connected to temporarily increasing continentality of climate conditions which are related to the advection of very cold and dry polar continental air masses from the east, sometimes even with the mixture of very cold arctic air masses. During such conditions deep soil frost increases, which does not allow the water infiltration into deeper layers. Thus, almost all melting snow is transformed into spring surface run-off volume and only a negligible part of this volume is transformed into groundwater. Such conditions may lead to the occurrence of very dry spells in spring. In spring, moderate droughts prevailed still in the period 1851-1950 (usually 4-6 cases), with a greater frequency in the first 50-year period. Both severe and extreme droughts were most frequent (usually 1-3 cases) in 1851-1900 and in particular in 1951-2000 (Fig. 10). In summer there is a clear change in the time pattern of drought occurrence: drought frequency rises in the 20th century (except severe droughts) and in the case of moderate droughts particularly in its second half. Frequency of extreme droughts is evidently higher in the 20th century compared to the pre-1900 period. In autumn, moderate droughts do not show great changes in the last two centuries, while severe and extreme droughts were most frequent in the 20th century (Fig. 10).

The frequencies of droughts per century calculated for different durations (2, 3 months, etc.) are shown in Fig. 11. The greatest number of all-category droughts occurred in Gdańsk (165) and in Żagań/Wrocław (155), while the smallest was in Kraków (104). In line with expectations, moderate droughts clearly dominate (55-75). The number of severe and extreme droughts is more or less comparable, most often ranging between 25 and 40. Both of these two categories of droughts were most frequent in the coastal part of Poland and least frequent in Lesser Poland (Fig. 11). Most droughts lasted 2 months (about 60\%-70\%) and then 3-4 months (10\%$20 \%$ ). The frequency of droughts of 5-or-more months was less than $10 \%$. The longest droughts had durations of $7-$ 8 months and occurred in Gdańsk from January to July of 1771, in Wrocław from March to September of 1805, in Poznań from May to November of 1874, in Torun from March to September of 1900, and in Wrocław (again) from August 1953 to March of 1954 (8 months).

Łabędzki (2007) proposed a simple formula to calculate the frequency of occurrence of dry months and droughts per century based on SPI values (see Methods section). Using his formula we calculated frequencies of dry months using SPI1, short-term droughts (SPI3), and long-term droughts (SPI24), including three categories of them (see Fig. 12). Analysis of this figure shows that the number of dry months in Poland usually ranges around 350 per century (100-year period (from 342 in Orzysz/Mikołajki to 366 in Poznań). The number of short-term droughts (SPI3) for Poland as a whole is comparable and usually ranges around 120 per century (from 119 in Koszalin to 127 in Wrocław and Kraków), while the frequency of long-term droughts (SPI24) is 15-16 per century. The short-term droughts distinguished here using SPI3 are most comparable to droughts delimited using the method proposed in the paper. Ratios of frequencies between moderate, severe, and extreme droughts are generally similar in both methods (Figs. 11 and 12), although in the Łabędzki method there is a greater domination of moderate droughts over the other two categories. Severe droughts are also clearly more numerous than extreme droughts (Fig. 12), which is not so clearly visible in drought frequencies calculated using our method (Fig. 11).

\subsection{Selected megadroughts in Poland from historical times}

Based on detailed analysis of all documentary evidence gathered for the period 1451-1800 we distinguished 17 megadroughts (also referred to in the paper as "extreme droughts", index -3) in Poland (see Fig. 5). Six of them - the most severe (Fig. 13) - have been chosen for more detailed presentation here. The main features of each megadrought are described (e.g. time of occurrence, duration, geographical area, consequences for nature, socio-economic impact). 

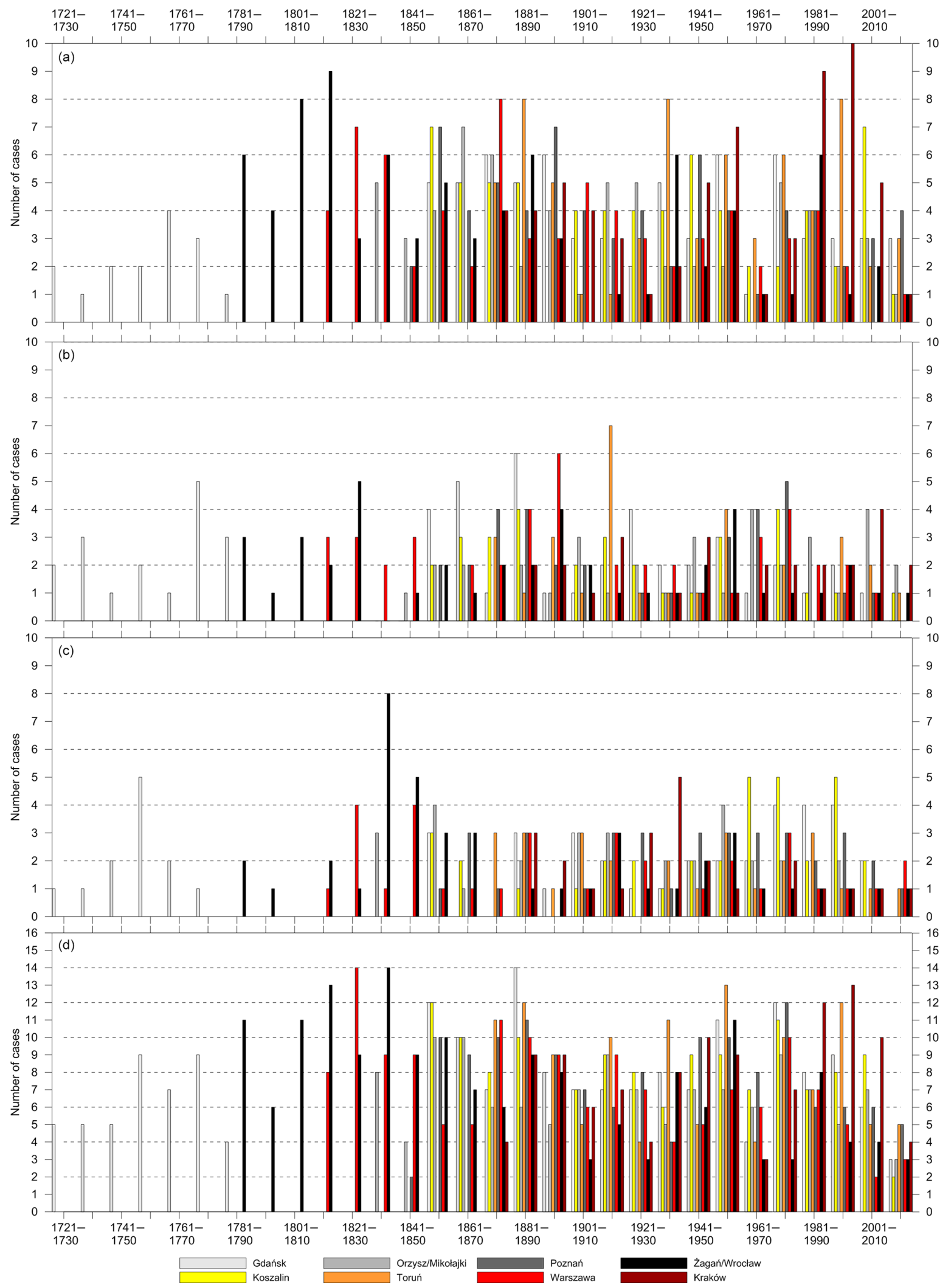

Figure 9. Decadal frequency of droughts in Poland in 1722-2015 identified using SPI1. Key: (a) moderate droughts, (b) severe droughts, (c) extreme droughts, and (d) all-category droughts. 


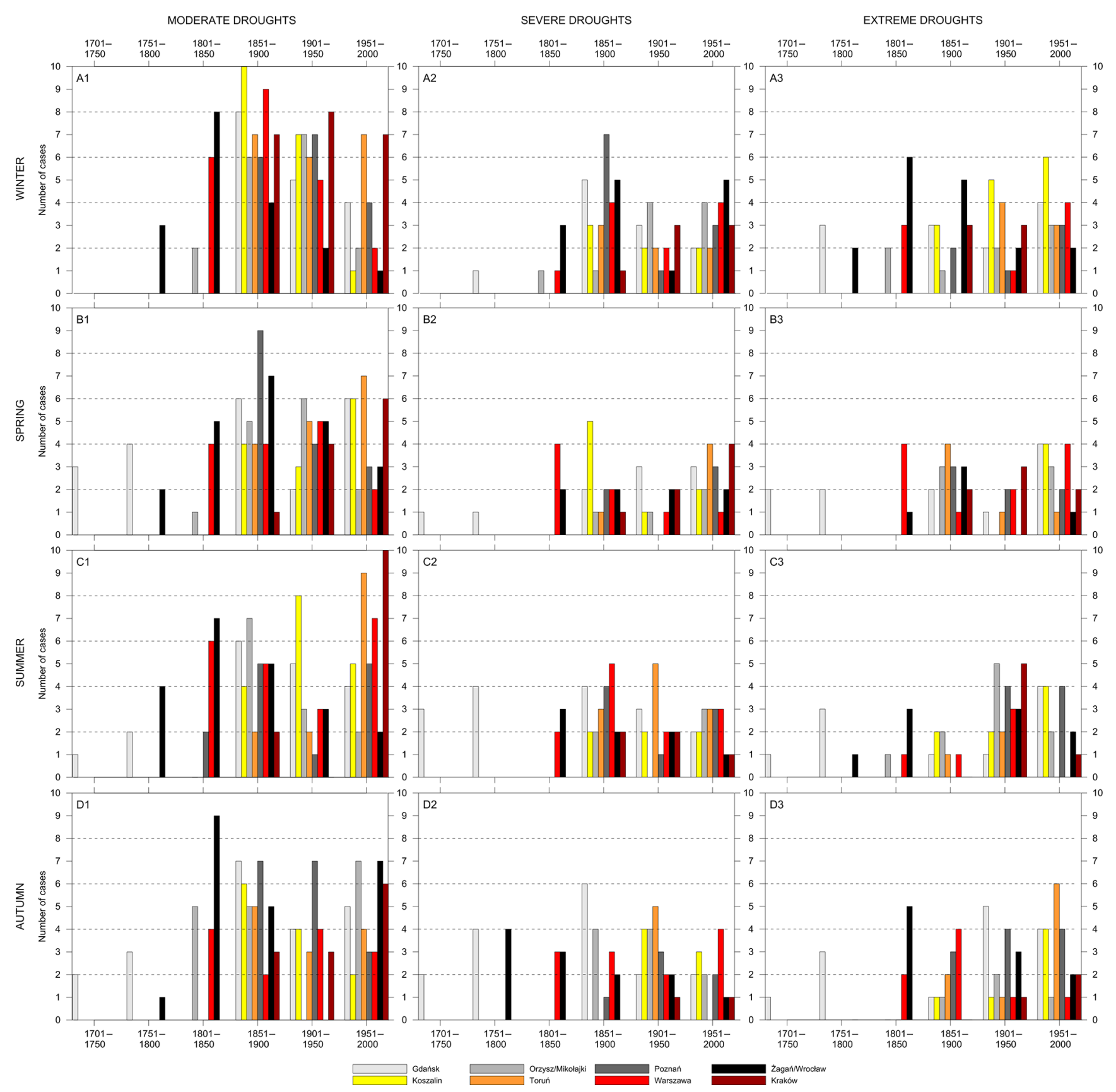

Figure 10. Seasonal 50-year frequency of droughts in Poland in 1722-2015 identified using SPI1.

\subsubsection{The year 1473}

This drought affected the whole of Europe. In the case of Poland, it was quite well described by Jan Długosz in Annales, as Długosz himself observed its course. He wrote about extraordinary heat and a prolonged lack of rain. He emphasised the extremely low level of water in the Wisła river and many other rivers that could be easily waded across. Water reservoirs were completely dry. The lack of water was marked throughout the whole country. Fires were an- other commonplace phenomenon. There were forest fires. Długosz also mentioned economic consequences. Fires destroyed wild beehives in the forests. Drought destroyed the spring sowing. Animals got sick. Fires affected such cities as Kraków, Wieliczka, Konin, Bełz, Chełm, Lubomia, Łęczyca, Sandomierz, and others (Długosz Ks.) (see Fig. 13). According to the Silesian chronicler Peter Eschenloer, the drought lasted from 23 April to 11 November. This chronicler recorded an extremely low level of water in the Odra river. Water mills could not operate. There was no water in 


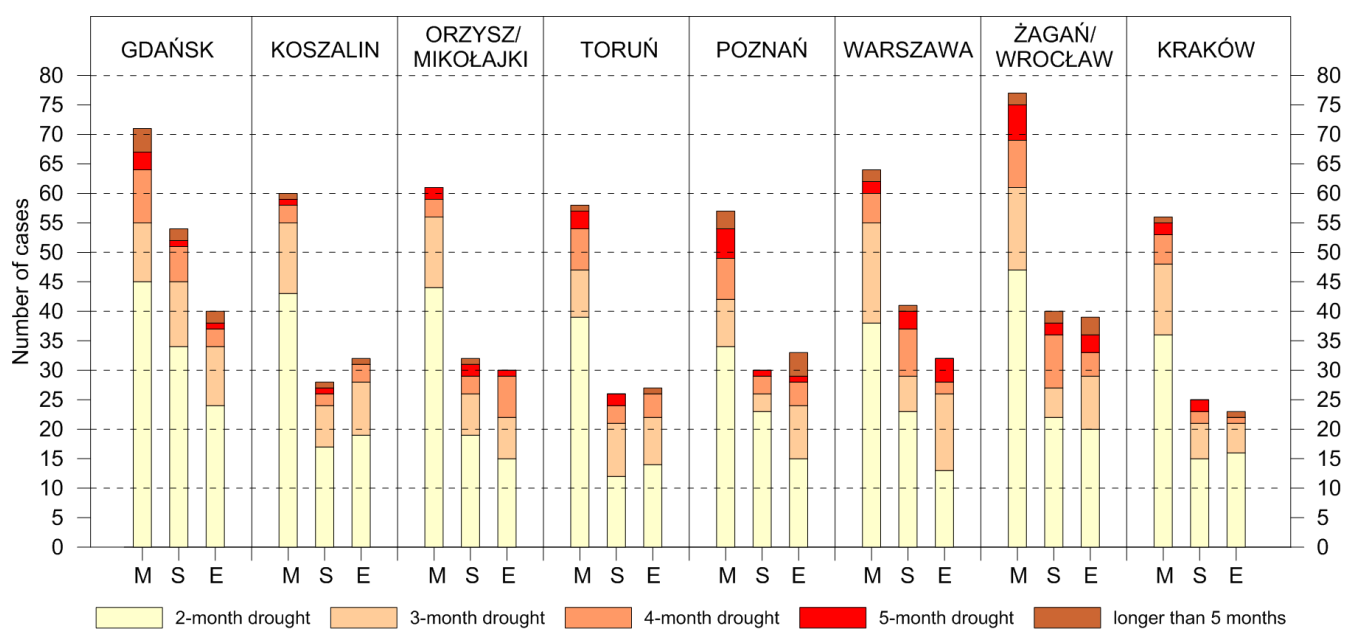

Figure 11. Average frequency of three categories of droughts (M: moderate, S: severe, E: extreme) in Poland per century stratified by duration (1722-2015).

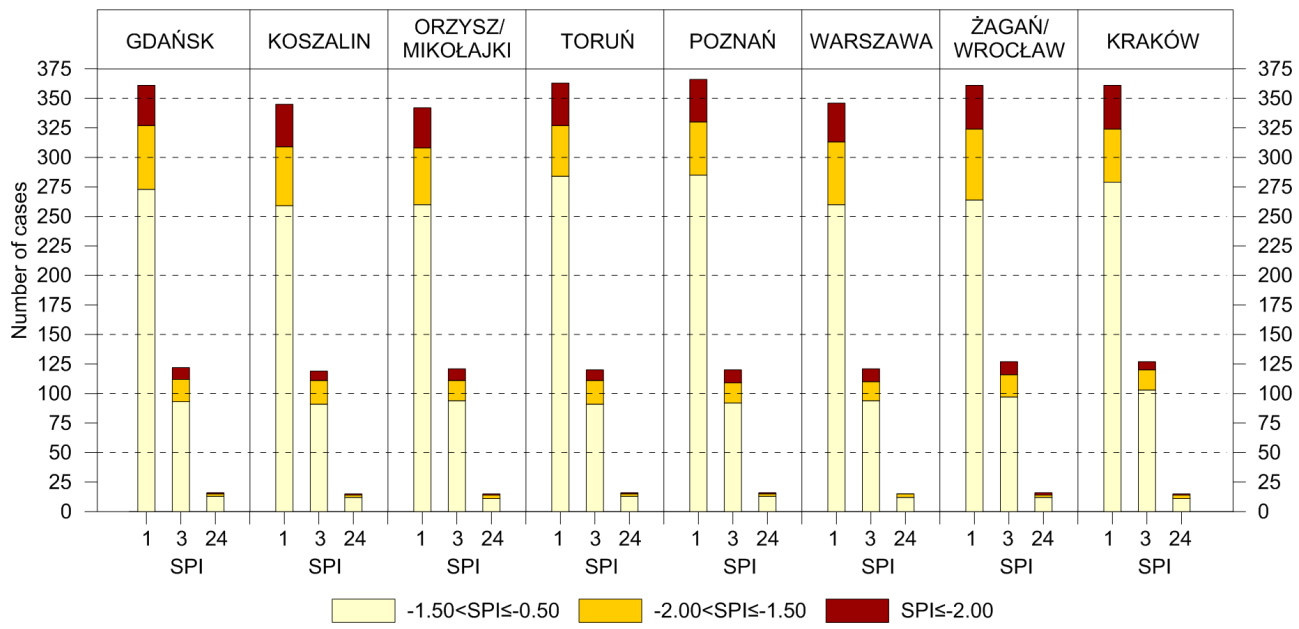

Figure 12. Frequencies of dry months (SPI1), short-term droughts (SPI3), and long-term droughts (SPI24) in Poland, including three intensity categories calculated using Łabędzki's formula.

wells. Even wild animals were affected by the lack of water. Similar information was provided by another Silesian chronicler, Nicolaus Pol. Meanwhile, the author of Roczniki gtogowskie, Kaspar Borgeni, reported that the drought lasted only 10 weeks. However, he provided many detailed dates in his narrative about the harvest time and its quality; there was no rain from 4 April to 22 September, so it should be considered that the drought lasted almost 6 months.

\subsubsection{The year 1540}

This drought belongs to one of the best-described droughts in old Europe. In Poland, however, the year 1540 began with numerous floods in the winter (Poznań) and early spring (Żuławy and Gdańsk). Heavy rainfalls also caused floods in Świecie located on the Wisła river in its lower part. Polish sources are quite laconic, if unambiguous, about the drought of 1540, considering its scale. A parish priest from Lidzbark Warmiński wrote about a terrifying drought. The Silesian chronicler Nicolaus Pol wrote about the drying of many waters and the greening of the Odra river, probably as a result of the development of algae at high temperatures. It was reported that grass was drying out, cereal harvests were poor, cattle had to go many miles to watering places. The detailed observations of the Kraków professor Marcin Biem leave no doubt as to the lack of rainfall and the extreme nature of the drought in the vicinity of Kraków. The drought lasted until October. There were many fires, including in such cities as Kwidzyn, Welawa, Klaipeda in the Prussian state, Gąbin in Mazowsze, and Radzyń Podlaski (see Fig. 13). Fires were also reported in Iława and Szczecinek (Nowosad and Oliński, 2019). 


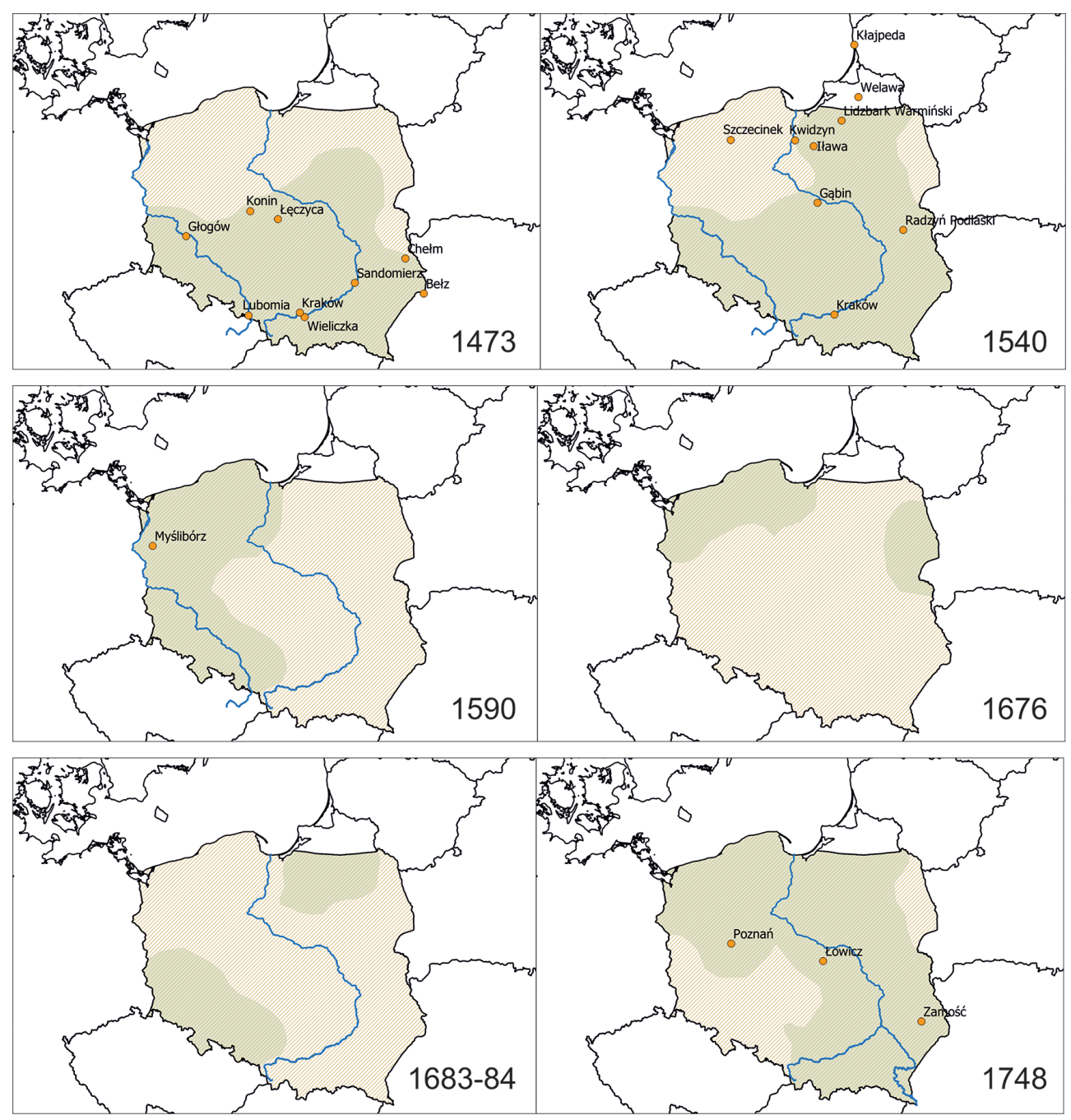

Figure 13. The most severe megadroughts, with spatial coverage (dark colour). Locations of sites and rivers mentioned in Sect. 4.4 and Table 3 are shown.

\subsubsection{The year 1590}

The winter of $1589 / 90$ was quite harsh, and rivers froze. There must certainly have been spring thaws. In the literature, mention is made of there having been no rain for 38 weeks. In the vicinity of Myślibórz on 4 May there was a severe frost, followed by a strong heat. There were also heavy storms. The phenomena resulted in numerous fires. From the end of May there was an uninterrupted rainless heat that lasted for a very long time. The duration of the heat was determined to have lasted 38 weeks, which is probably a mistake. Rivers dried up, the river mills stopped working. Prices rose significantly (Reinhold, 1846, p. 143; Girguś et al., 1965, p. 182). The dry summer and the drying of many rivers were also mentioned in reference to Silesia and the Karkonosze mountains (Bergemann, 1830a, b). The level of the Wisła river was also extremely low. The drought therefore affected all Polish areas and lasted continuously from the end of May to the end of autumn. Many of its manifestations (total lack of rainfall, drying of rivers, high temperatures, consequences for agriculture and nature) indicate its extreme character.

\subsubsection{The year 1676}

The drought of 1676 was described independently in several sources. Spring is supposed to have abounded in storms that caused numerous fires. There was drought in the summer. In Pomerania (see Fig. 13) it rained only twice in the summer. The whole summer was dry and hot. The drought caused damage to crops in slightly higher areas. The harvest of fruits and vegetables was also poor due to the drought. In Podlasie, the beginning of January was exceptionally warm, although frosts arrived later. According to the records from Antoni Chrapowicki's diary, June and July were very dry months in Podlasie. Chrapowicki wrote that crops "burned 
out" in the fields. In August and September, Chrapowicki stayed in eastern Belarus, which is why his records concerning the late summer and autumn cannot be taken into account (Diaryusz Życia JWJmci Pana Jan Antoni Chrapowicki). The research into the memoirs of Chrapowicki indicates that the precipitation in 1676 was the slightest of all the years covered by his diary (1656-1684) (Przybylak and Marciniak, 2010). In other sources, the high prices that prevailed in the country that year were also underlined (Namaczyńska, 1937).

\subsubsection{The years 1683-1684}

It is known from later record that a great drought was recorded in Masuria in 1683. It caused a lack of crops and high prices. In Poland in 1684, after a harsh winter, a hot, dry summer came. The drought resulted in earlier, but thus weaker, harvests of winter grain and the destruction of spring crops. Water reservoirs dried up. There were not enough watering places for animals (Namaczyńska, 1937). According to Silesian sources, the drought came on 24 June 1684; it destroyed grain and flax and burned grass. Cattle died for a lack of grass and water. Prices were very high (Gomolcke, 1737 , p. 32-33, 54). From various sources it can be established that the drought began at the end of June and continued until September 1684.

\subsubsection{The year 1748}

The winter was quite long. In Gdańsk, on 7 April, there was ice floe on the Motława river. In the vicinity of Torun the ice on the Wisła river did not start to melt until the beginning of April. Near Torun, the Wisła river flooded adjacent territories. The water level began to fall at the beginning of May. Beautiful, dry weather came, and it started to arouse farmers' anxiety about the growth of plants. On 25 May, it rained in Torun, but the intensity of precipitation was insignificant. The second half of May was considered to be extremely dry. In Gdańsk, heat and drought prevailed from 8 to 23 May. In Torun, on 7 June an increase was recorded in the water level in the Wisła river, which may indicate more significant rainfalls in the south of Poland. In the vicinity of Torun, rain fell after a long break, on 11 June, causing people to rejoice, but by 22 June dry weather was again recorded. In Gdańsk, in June, dry days prevailed, but they were interspersed with rainy days.

On 1 July, in Torun, it was recorded that there had been light rains from time to time, but, above all, a great drought had been felt. No fires had broken out in the vicinity yet, but they had in many places in Poland and Lithuania: fires were recorded in Poznań and Zamość (see Fig. 13). In Gdańsk, rainless weather prevailed throughout the first half of July, while in the second half there were only $5 \mathrm{~d}$ with rain. In midJuly, high prices resulting from the prolonged drought were reported. Transport on the Wisła river was extremely difficult due to the low water level. Information about the drought also came from other European countries. In addition, locusts appeared in Hungary and Transylvania. In Toruń and Gdańsk, rain fell for a few days after the solar eclipse of 25 July. Similar rains fell at that time in Warszawa. At the beginning of August, however, the drought was reported again. In Torun, rain fell on 5 August and then on 8 August. At that time, the water level in the Wisła river also increased for a short time, but, at the same time, there were reports of fires having destroyed Łowicz. In Torun, the drought prevailed until the end of August and the first half of September. In Gdańsk, the whole month of August was very dry. Rain fell there in early September, but in the following days the drought returned and did not stop until mid-September. The autumn was very cold. The end of the drought was not seen in Torun until midOctober, but complaints about the very low water level in the San river were still being reported (Reyger, 1770; Oliński, 2002).

\section{Discussion}

Every climate proxy has its own advantages but also its weaknesses. Therefore, to increase the probability of correctly dating drought in Poland, we decided to use both documentary evidence and dendrochronological data for the period before the 19th century. A satisfactory number of data obtained from both kinds of proxies are available for the period 1451-1800, allowing for reliable cross-checking of information about the occurrence and characteristics of droughts. For the most recent period (1801-2015), the usefulness of tree-ring data in describing dry spells (droughts) was checked by comparing it against droughts delimited for the area of Poland using SPI calculated for eight long-term series of monthly precipitation totals.

Tree rings in Poland can be a source of information about both hydroclimate phenomena, such as droughts, and air temperature (Büntgen et al., 2007, 2011; Koprowski et al., 2012; Opała and Mendecki, 2014; Opała, 2015; Pritzkow et al., 2016; Balanzategui et al., 2017). The key issue is to isolate which factor strongly influences tree-ring growth. Up till now, tree-ring widths in Poland have been used only for air temperature reconstructions (e.g. Przybylak et al., 2005; Szychowska-Krąpiec, 2010; Niedźwiedź et al., 2015). In the present paper, this kind of proxy data is used for the first time to identify drought occurrence in the vegetation period. It was assumed that the combined information from historical and instrumental sources, on the one hand, and dendrochronological sources, on the other hand, would be crucial in identifying the strength of water shortage and the occurrence of droughts in Poland in recent centuries.

Extreme and severe drought occurrence in spring and summer, as identified by documentary data, corresponds closely with the occurrence of negative pointer years (droughts). In the period 1451-1800, 48 severe and extreme droughts in the mentioned seasons have been determined to have oc- 
curred across all of Poland or in at least two geographical regions (see Fig. 1). Dendrochronological data showed significantly smaller rings having formed during $52.1 \%$ of these. Dobrovolný et al. (2015) found very similar results for the Czech Republic based on a set of 3194 oak-ring-width samples for the last 1250 years (761-2010). Negative tree-ringwidth extremes were confirmed in documentary sources in $53 \%$ of cases. Analysis of extreme and severe droughts that occurred in only one geographical region in Poland reveals a better correspondence between analysed proxies than those described earlier for the greater area of Poland (at least two regions). In that case negative pointer years in tree rings were noted in as many as $59.1 \%$ of detected droughts by historical sources.

Even better agreement between both kinds of proxy data was found when megadroughts identified by documentary evidence were taken into account. In four $(1473,1540,1590$, and 1748) of the six described here (see Sect. 4), clear signals in dendrochronological data were detected (negative pointer years). Using documentary sources, two megadroughts (1540 and 1590) were also qualified as very outstanding droughts in the Czech Republic (Brázdil et al., 2013). Of those, however, only the year 1590 had a negative tree-ring width index (TRW) (of -1.818 ), although this value was not very high (see Table S1 in the Supplement in Dobrovolný et al., 2015). Brázdil et al. (2013) using documentary evidence also distinguished three other outstanding droughts in the Czech Lands (1616, 1718, and 1719). All of those also occurred in Poland, but their category using documentary evidence was estimated by us as -2 (severe). In all those years except 1718, negative pointer years were also found in one Polish region (see Fig. 6), while in the Czech Republic an extreme negative TRW index (-2.474) was found only for the year 1616 (see Table S1 in the Supplement in Dobrovolný et al., 2015). Based on the published list of TRW indices for Czech Republic (oak chronology) by Dobrovolný et al. (2015), we found 33 extreme, negative TRW indices in the period 1451-1800, which suggests favourable conditions for drought occurrence. We excluded the two last years (1790 and 1800), which were identified for Scots pine tree rings from Upper Silesia (Opała and Mendecki, 2014). For almost half of this set of years ( $48.5 \%$ ), we confirmed the existence of strong, negative pointer years also in Poland's tree dendrochronologies. Significantly better agreement (89\%), between the occurrence of narrow rings in the Czech Republic on the one side and Upper Silesia (Opała and Mendecki, 2014) and southern Poland (Opała, 2015) on the other, was found by Dobrovolný et al. (2015) for the overlapping period 1770-1932. These quite good correspondence patterns between negative TRW in the Czech Republic and Poland (in particular its southern part), which are also very clear in the analysis of drought occurrence and areal coverage (which are presented in the Old World Drought Atlas, OWDA; Cook et al., 2015), are the result of large, positive sea-levelpressure anomalies over the whole of central Europe (in- cluding Poland) in MAM and JJA during the occurrence of negative extremes in TRW (see Fig. 5 in Dobrovolný et al., 2015). Significantly weaker agreement (about $30 \%$ ) was found between the timings of droughts in Poland delimited using documentary evidence and droughts reconstructed for the whole of Europe using tree rings (Cook et al., 2015). This is caused by the fact that Cook et al. (2015) used significantly fewer dendrochronologies from Poland (only four - and those mainly from northern Poland; see their Supplementary Materials) than we used in the present paper (22; see Table 1 for details).

The megadrought year of 1473 was detected in the Baltic province on the basis of an oak chronology from eastern Pomerania (Ważny, 1990). Narrow rings were observed in $80 \%$ of the samples for this year. The effect of the drought in 1473 can also be shifted and observed in southern Poland in 1474 (Szychowska-Krapiec, 2010). Reconstruction based on dendrochronological data (OWDA; Cook et al., 2015) shows that, in this year, severe droughts were common in almost the entirety of Europe (but particularly in southern Germany, western Czech Republic, and Austria) excluding only its northern and north-eastern parts and Spain. The drought in 1540 was observed in different parts of Europe; particularly strong evidence is available in documentary sources (Wetter et al., 2014; Pfister et al., 2015; Brázdil et al., 2016). Additionally, many dendrochronological data confirm the existence of strong droughts in much of Europe, in particular from France to Latvia, Belarus, and Ukraine and from the southern Scandinavian Peninsula to northern parts of Italy (OWDA; Cook et al., 2015).

Čufar et al. (2008) identified the existence of droughts in Slovenia in 1540 based on tree rings. The scale and intensity of the 1540 megadrought in Europe described by Wetter et al. (2014) as "an unprecedented 11-month-long megadrought" (more severe than the 2003 drought in western Europe and the 2010 drought in Russia) were, however, recently questioned by Büntgen et al. (2015), who analysed this year in light of a measurement series of 24303 individual tree-ring widths. It is also worth adding here that in different parts of Europe the effect in tree rings was shifted and observed in 1541 (Büntgen et al., 2011). Analysis of our 22 dendrochronologies reveals the occurrence of narrow rings in trees growing in the Baltic province and in the Lesser Poland province, and thus not in the whole of Poland as shown in the OWDA (Cook et al., 2015). In 1590, narrow rings were observed in the Baltic province, but the decidedly strongest droughts in Europe in view of this proxy were those occurring in France and Germany (Cook et al., 2015). Narrow rings were also noted in most sites in central and eastern Europe, as well as in Scandinavia. The megadroughts occurring in Poland in the 17th century (1676 and 1683-1684) were the least territorially extensive of all the megadroughts analysed here (see Fig. 13). Analysis of tree-ring reconstructed droughts (Cook et al., 2015) generally confirms this, except for the year 1684. In all those years strong droughts were 
common in Europe also; their greatest intensity was observed in Germany, France, the Low Countries, and England (1676 and 1684) but in southern Europe in 1683. The year 1748 seems to have a somewhat regional character; narrow rings were noted in the Greater Poland and Pomerania provinces and in the Lesser Poland province. There is no information about tree reaction for this drought in selected sites in central Europe (Büntgen et al., 2011). Looking at OWDA we see the occurrence of droughts in this year mainly in northern and western parts of Poland (although their severity is not so large). Evidently more severe droughts in this year in Europe were particularly observed in southern Germany, the whole of Austria, and the western borders of the Czech Republic (Cook et al., 2015).

Both documentary evidence and dendrochronological data clearly indicate that in the period 1451-1800 the greatest frequency of droughts in Poland occurred in the 18th century, and particularly in the second half (32 cases). Similar results are also seen in the Czech Republic (see Fig. 4a in Brázdil et al., 2013). The smallest number of droughts was noted in the 16th century (about 35), and it was different than in the Czech Lands, where the evidently smallest number occurred in the 17th century. In the study period, the total number of all-category droughts in Poland identified reached 148 and 156 - using documentary evidence and dendrochronological data, respectively. This means that both proxies reconstruct quite a similar frequency of drought occurrence in timescales from centuries to decades. The overall numbers of droughts identified using documentary evidence in Poland (present study) and the Czech Lands (Fig. 4a in Brázdil et al., 2013) in the overlapping period 1501-1800 were very similar and reached 132 and 126 cases, respectively.

All the dendrochronologies and long-term series of precipitation that we gathered and used for SPI calculation are available only for the common period 1876-1985. Therefore, for this period, statistics were calculated to compare the timings of dry periods (droughts) in Poland identified using both of these kinds of data. The agreement between droughts occurring at least in two geographical (SPI $1_{\text {May-Jul }}$ delimited droughts) and two natural-forest regions (significant negative pointer years) was $25.5 \%$. On the other hand, for a less strict criterion, i.e. the occurrence of droughts at least in one region, the agreement reached $50.9 \%$. Thus, the latter number is close to the value of agreement of drought timings identified using documentary evidence and the occurrence of negative pointer years $(59.1 \%)$.

Having those series for the above-mentioned period, we also conducted a correlation analysis to investigate how spatially coherent the association is between climate (SPI1 $1_{\text {May-Jul }}$ ) and tree-ring widths in the area of Poland. Coefficients of Pearson's linear correlation were calculated for 1-2 dendrochronologies representing each natural-forest region, with SPI1 May-Jul values calculated for long-term series of precipitation taken from meteorological stations in the same region and closest to the area covered by the den- drochronologies. The closest relationships between climate and tree-ring growth were obtained for the Greater Poland and Pomerania provinces and the Silesia province, where the correlation coefficient $r$ reached 0.40 (site 9, Poznań in Table 1), 0.44 (site 11, Kuyavia-Pomerania), and 0.46 (site 17, Wrocław). Such good correlation $(r=0.43)$ was also found by Dobrovolný et al. (2015) for the Czech Republic between 18 variants of Czech oak chronology and March-June precipitation totals. In three other Polish provinces (Baltic coast, Masuria, and Masovia; see Fig. 1) correlation coefficients are still statistically significant, but they are clearly smaller: 0.25 (site 3, Wolin in Table 1), 0.14 (site 1, Koszalin), 0.24 (site 7, Suwałki), 0.13 (site 8, Hajnówka), and 0.21 (site 15, Warszawa). A similar correlation value (about 0.20 ) between tree-ring width and precipitation in June and July was found by Helama et al. (2014) for south-western Finland. On the other hand, a significantly better correlation (about 0.4) was calculated by Seftigen et al. (2013) for south-eastern Sweden. The increased strength of correlation here was probably due to the selection of trees growing at xeric sites, where the radial growth was most likely limited by moisture availability. The climate-tree-ring-growth relationship in Lesser Poland province was not stated - the coefficient of correlation was equal to 0.0 . The reasons for this different climatetree-growth behaviour in this part of Poland in comparison to other studied regions are unknown.

From the perspective of available historical sources from the period 1451-1800, an increasing number of droughts were reported from the second half of the 16th century onwards, excluding the first half of the 17th century. The decrease in their occurrence in this period can be explained by large source deficiencies. They resulted from the destruction of many documents during the Swedish invasion of Polish territories in 1655-1660. The number of droughts in the first half of the 17th century is likely to have been higher. Summer and winter air temperature reconstructions for Poland for the period 1401-1800 (see Przybylak, 2011, 2016) indicate that thermal conditions were more favourable for the occurrence of droughts in the first half of the 17th century than in the period 1751-1800, which was colder. Only in the second halves of the 15th and 16th centuries were conditions better for the occurrence of summer droughts than in the first half of the 17th century. This means that the low number of droughts in the latter period is not the result of climate but is of the significantly smaller number of available sources, as we mentioned earlier.

As information about moderate droughts is quite accidental, the sources certifying extreme and severe droughts seem more reliable and complete. According to our research, droughts occurred most frequently in the second half of the 18th century. This rectifies the previously accepted data on drought in Poland available in some geographic works (see Słota et al., 1992; Kaca et al., 1993; Łabędzki, 2006), which include information that in the 14th century there were 20 droughts in Poland, 25 in the 15th century, 19 in the 16th cen- 
tury, 24 in the 17th century, and 22 in the 18th century. However, these numbers refer to the frequency of hot summer seasons distinguished by Sadowski (1991; Sadowski also assumed the years 1300,1400 , etc. to be the first years of a century). On the basis of the research presented in this paper, we conclude that severe and extreme droughts (indexes $-2,-3$, respectively) were in fact slightly less frequent, while their occurrence in the period from the 15th to the 18th century, as previously stated, was slightly increasing.

\section{Summary and concluding remarks}

The main results of the present paper can be summarised as follows:

1. More than 100 droughts were found in documentary sources from the mid-15th century to the end of the 18th century, including 17 megadroughts. A greater than average number of droughts were observed in the second halves of the 17th century and the 18th century in particular. Dendrochronological data confirmed this general tendency in the mentioned period. The clearly greatest number of negative pointer years occurred in the 18th century and then in the period 1451-1500.

2. Droughts in the period 1451-1800 occurred most frequently in the Baltic coast-Pomerania and Silesia regions, while in the rest of the analysed regions their frequency was more or less similar. Generally similar results have been found for the period 1722-2015 based on instrumental data.

3. Analysis of SPI (including its lowest values - droughts) showed that the long-term frequency of droughts in Poland has been stable in the last two or three centuries.

4. Most droughts in the period 1722-2015 lasted for two months (about $60 \%-70 \%$ ), and the next most common duration was 3-4 months (10\%-20\%). Frequencies of droughts of 5-or-more months were below $10 \%$. The longest droughts lasted for 7-8 months.

5. The frequency of all-category droughts in Poland in the period 1722-2015 was greatest in winter. This fact should be taken into account when droughts delimited using documentary evidence are analysed. In light of this information, droughts in spring and summer clearly dominated in Poland in the period 1451-1800, while in winter only three cases were mentioned.

6. Analysis of the occurrence of negative pointer years (a good proxy for droughts) showed a good correspondence with droughts delimited based on documentary and instrumental data in the periods 1451-1800 and 1722-2015, respectively.
Our study supports the usefulness of both kinds of proxy data as reliable tools for delimiting and characterising droughts for the pre-instrumental period in Poland. Information about droughts received from historical and dendrochronological data very often complete each other. In some cases where it is difficult to reliably categorise droughts based on historical sources, the occurrence of narrow rings in trees from different regions and their magnitude can significantly help in final and more reliable categorisation of this phenomenon. Such a possibility appears to be very important due to the fact that the historical data are based on subjective observations. On the other hand, the information received from old historical documents can also be useful for indicating reasons for the occurrence of the narrow rings noted in trees (droughts, insects, etc.). As long as historical buildings in Poland continue to be incompletely investigated for wood dating, and not all historical documents are analysed for the study of old weather conditions, knowledge about droughts will be incomplete, and further work is thus needed. 


\section{Appendix A}

\section{A1 Main archival sources used}

Annales Conradi Molleri, meist Thorn angehend, Archiwum Państwowe w Toruniu, Akta miasta Torunia, Kat. II, XIII-12

Brauer Dawid, Geschichte der Stadt Thorn, zum Teil auch der Lande Preußen, vol. 1-3, Archiwum Państwowe w Toruniu, Akta miasta Torunia, Kat. II, XIII-54, XIII-54a, XIII-54b.

Diaryusz Życia JWJmci Pana Jana Antoniego Chrapowickiego Wojewody Witebskiego [...] przekopiowany w roku 1786, T. 3 [1670-1673], Muzeum Narodowe w Krakowie, rps. MNKr. 169

Diaryusz Życia JWJmci Pana Jana Antoniego Chrapowickiego Wojewody Witebskiego [...] przekopiowany w roku 1786, T. 4 [1674-1676], Muzeum Narodowe w Krakowie, rps. MNKr. 169

Diaryusz Życia JWJmci Pana Jana Antoniego Chrapowickiego Wojewody Witebskiego [...] przekopiowany w roku 1786, T. 5 [1677-1679], Muzeum Narodowe w Krakowie, rps. MNKr. 169

Diaryusz Życia JWJmci Pana Jana Antoniego Chrapowickiego Wojewody Witebskiego [...] przekopiowany w roku 1786, T. 6 [1680-1682], Muzeum Narodowe w Krakowie, rps. MNKr. 169

Diaryusz Życia JWJmci Pana Jana Antoniego Chrapowickiego Wojewody Witebskiego [...] przekopiowany w roku 1786, T. 7 [1683-], Muzeum Narodowe w Krakowie, rps. MNKr. 169

Korespondencja Michała Dorengowskiego, Archiwum Główne Akt Dawnych, Archiwum Radziwiłłowskie, Dz. V, 3207/II

Muzeum Narodowe w Krakowie, rps. 169, p. 82

Richtsteig Johann, Chronikalische Aufzeichnung Thorner und Thorn angehende Begebenheiten, 2. vol., Archiwum Państwowe w Toruniu, Akta miasta Torunia, Kat. II, XIII-80, XIII-80a

Żegota Pauli, Notaty z Kalendarzy dawnych krakowskich w. XV, XVI i XVII, Biblioteka Jagiellońska w Krakowie, Rękopis nr 5358
Curicke Reinhold, Der Stadt Dantzig historische Beschreibung, Amsterdam und Dantzig 1688

Gomolcke Daniel, Historische Beschreibung derer grossen Theuerungen, Hunger und Kummerjahre, welche nicht allein die k.u.k. Stadt Breslau, sondern auch das gantze Land Schlesien bis auf das 1737 Jahr betroffen, Breslau 1737.

Happel, Eberhard Werner, Kern-Chronica der merckwürdigsten Welt- und Wunder-Geschichte mit beygefügten nöthigen Registern und Anweisungen, auch sehr vielen Kupfern Hamburg 1690

Kochowski Wespazjan, Annalium Poloniae ab obitu Vladislai IV. Climacter I-III, Cracoviae 1683-1698

Kronika Marcina Bielskiego (Zbiór dziejopisów polskich, 1), Warszawa 1764

Miechowita Maciej, Chronica Polonorum, Cracoviae 1521

Nicolai Henelius ab Hennenfeld Annales Silesiae, in: Silesiacarum rerum scriptores, edited by: von Sommersberg, F. W., Leipzig 1730

Theatrum Europaeum... das ist ausführliche Beschreibung der denckwürdigsten Geschichten, so sich hin und wieder durch Europa, wie auch in denen übrigen WeltTheilen, von Jahr 1618 an ..., Franckfurt am Mayn 1663-1707

Zerneke J. H., Historiae Thoruniensis naufragae tabulae, Thorn 1711

A3 The old press

Kuryer Polski, Anno 1730 (Nr 15), 1739 (Nr 129, 133),

Kuryer Warszawski, 1763 (nr 75)

Thornische wöchentliche Nachrichten und Anzeigen nebst einem Anhange von gelehrten Sachen, Erstes Jahr 1760

\section{A4 Printed sources}

Annales Glogovienses bis z. J. 1493, ed. by Hermann Markgraf, in Scriptores rerum Silesiacarum, vol. 10, Breslau 1877, p. 1-66.

Archivum vetus et novum Ecclesiae Archipresbyterialis Heilsbergensis, in "Scriptores Rerum Warmiensium oder Quellenschriften zur Geschichte Ermlands", ed. by Woelky Carl P., vol. 2, Braunsberg 1880, p. 587-758 
Biblioteka starożytna pisarzy polskich, ed. K. Wł.. Wójcicki, Vol. 6, Warszawa 1844

Catalogus abbatum Saganensium, in Scriptores rerum Silesiacarum, vol. 1, ed. by Gustav Adolf Stenzel, Breslau 1835 , p. $173-528$

Chrapowicki Jan Antoni, Diariusz, Vol 1-2: ed. by T. Wasilewski, Warszawa 1988

Chronik Michael Steinbergs, ed. by T. Schöborn, in Scriptores rerum Silesiacarum, vol. 11 (Schweidnitzer Chronisten des XVI. Jahrhunderts), ed. by Schimmelpfennig, Breslau 1878, p. 117-176

Die Thammendorf'sche Familienchronik, ed. by A. Schimmelpfennig, in Scriptores rerum Silesiacarum, vol. 11 (Schweidnitzer Chronisten des XVI. Jahrhunderts), ed. by Schimmelpfennig, Schönborn, Breslau 1878, p. 1-58.

Długosza Jana Roczniki czyli Kroniki sławnego Królestwa Polskiego, 2. vol.: 12, 1445-1461 and 14621480, ed. by Krzysztof Baczkowski et al., Warszawa 2009

Dupont Philippe, Pamiętniki historyi życia i czynów Jana III Sobieskiego, ed. by Dariusz Milewski, transl. by Beata Spieralska, Warszawa 2011

Kronika walichnowska (1703-1725), wyd. ks. A. Mańkowski, Zapiski TNT, t. 8, R. 1930

Kuczyński Wiktor, Pamiętnik 1668-1737, ed. by Józef Maroszek et al., Białystok 1999

Latopisiec albo kroniczka domowa Joachima Jerlicza, ed. K. W. Wójcicki, Vol. 2, Warszawa 1853

Marcin Murinius, Kronika albo krótkie z kronik rozmaitych zebranie spraw potocznych ziemie $\mathrm{z}$ dawna sławney pruskiey, ed. by K. W. Wójcik (Biblioteka starożytnych pisarzy polskich, IV), Warszawa 1843

Nicolaus Pol, Jahrbücher der Stadt Breslau, ed. by Johann Gustav Gottlieb Büsching, Johann Gottlieb Kunisch, vol. 1-5, Breslau 1813-1824

Niezabitowski Stanisław, Dzienniki 1695-1700, oprac. i wstęp A. Sajkowski, Poznań 1998

Ossoliński Zbigniew, Pamiętnik, ed. by Józef Długosz, Warszawa 1983

Pamiętniki Łosia obejmujące wydarzenia 1646-1667, ed. by Pauli Żegota, Kraków 1858
Pasek Jan Chryzostom, Pamiętniki, ed. by Roman Pollak, Warszawa 1963

Peter Eschenloer, Geschichte der Stadt Breslau, Vol. 12, ed. by Gunhild Roth, Münster-NewYork 2003

Peter Eschenloer, Historia Wratislaviensis et que post mortem regis Ladislai sub electo Georgio de Podiebrat Bohemorum rege illi acciderant prospera et adversa, ed. by Hermann Markgraf, in Scriptores rerum Silesiacarum, vol. 7, Breslau 1872,

Preussische Chronik des Johannes Freiberg: aus den auf der Königsberger Stadtbibliothek befindlichen Handschriften ed. by Friedrich Adolf Meckelburg, Königsberg 1848

RadziwiłłAlbrycht Stanisław, Pamiętnik o dziejach w Polsce, tom 1-3 1632-1656, oprac. A. Przyboś, R. Żelewski, Warszawa 1980

Rocznik Jana z Targowiska 1386-1491, ed. by Emil Kalitowski, in Monumenta Poloniae Historica, vol. 3, Lwów 1878, p. 232-240

Rocznik wrocławski dawny 1238-1308 i rocznik magistratu wrocławskiego 1149-1491, ed. by August Bielowski, in Monumenta Poloniae Historica, vol. 3, Lwów 1878, p. 680-688

Rzączyński Gabriel, Historia Naturalis Curiosa Regni Polniae, Magni Ducatus Lituaniae, annexarumque Provinciarum in tractatus XX divisa, Sandomiriae 1721

Sigismundi Rosiczii Chronica et numerus episcoporum Wratislaviensium, in Scriptores rerum Silesiacarum, ed by F. Wächter, Breslau 1883, vol. 12, p. 29-86

Skoraczewski F., Materyały do historyi Miłosławia, Poznań 1910

Spominki kazimierskie 1422-1473, ed. by August Bielowski, in Monumenta Poloniae Historica, vol. 3, Lwów 1878, p. 242-243.

Świętosława Orzelskiego Bezkrólewia ksiąg ośmioro 1572-1576, ed. by Edward Kuntze, in Scriptores rerum Polonicarum, vol. 22, Kraków 1917

Wernicke Julian Emil, Geschichte Thorns aus Urkunden, Dokumenten und Handschriften, 2. vol., Thorn 1839-1842 
Data availability. Drought indices constructed for the area of Poland for the period 1451-2015 are available at https://doi.org/10.18150/repod.3621839 (Przybylak et al., 2020). Dendrochronological data contained herein, but whose source databases or articles are not cited, are available upon request from Marcin Koprowski (koper@umk.pl). Other data used in graphs are available from the corresponding author.

Author contributions. Study design was done by RP, PO, MK, JF, and AP. Data collection was done by RP, AP, JF, PO, WCH, $\mathrm{MK}, \mathrm{RPu}$, and HPD. Statistical analysis was done by AP, PO, JF, $\mathrm{MK}$, and RPu. Interpretation of results was done by RP, JF, MK, $\mathrm{RPu}$, and PO. Preparation of manuscript was done by RP, PO, JF, $\mathrm{AP}, \mathrm{MK}$, and RPu. Literature review was done by RP, PO, MK, JF, $\mathrm{AP}$, and $\mathrm{RPu}$.

Competing interests. The authors declare that they have no conflict of interest.

Special issue statement. This article is part of the special issue "Droughts over centuries: what can documentary evidence tell us about drought variability, severity and human responses?". It is not associated with a conference.

Acknowledgements. The research work of Piotr Oliński and Rajmund Przybylak was supported by a grant entitled "Climatic conditions in South Baltic Areas in the second half of the 15th and 16th centuries and their consequences for social, economic and cultural life", funded by the National Science Centre, Poland (grant no. DEC-2013/11/b/HS3/01458). Radosław Puchałka was supported by a grant entitled "Xylogenesis and tree-ring chronologies in European beech (Fagus sylvatica) and Sessile oak (Quercus petrea) in the north-eastern margin of their natural range", funded by the National Science Centre, Poland (grant no. 2017/01/X/NZ8/00257). We also thank anonymous reviewers for their constructive and helpful suggestions and comments, which significantly helped to improve the article.

Financial support. This research has been supported by the National Science Centre, Poland (Climatic conditions in South Baltic Areas in the second half of the 15th and 16th centuries and their consequences for social, economic and cultural life (grant no. DEC2013/11/b/HS3/01458)) and (Xylogenesis and tree-ring chronologies in European beech (Fagus sylvatica) and Sessile oak (Quercus petrea) in the north-eastern margin of their natural range (grant no. 2017/01/X/NZ8/00257)).

Review statement. This paper was edited by Jürg Luterbacher and reviewed by three anonymous referees.

\section{References}

Alexander, L. V., Zhang, X., Peterson, T. C., Caesar, J., Gleason, B., Klein Tank, A. M. G., Haylock, M., Collins, D., Trewin, B., Rahimzadeh, F., Tagipour, A., Rupa Kumar, K., Revadekar, J., Griffiths, G., Vincent, L., Stephenson, D. B., Burn, J., Aguilar, E., Brunet, M., Taylor, M., New, M., Zhai, P., Rusticucci, M., and Vazquez-Aguirre, J. L.: Global observed changes in daily climate extremes of temperature and precipitation, J. Geophys. Res., 111, D05109, https://doi.org/10.1029/2005JD006290, 2006.

Allen, C. D., Macalady, A. K., Chenchouni, H., Bachelet, D., Mcdowell, N., Vennetier, M., Kitzberger, T., Rigling, A., Breshears, D. D., Hogg, E. H. T., Gonzalez, P., Fensham, R., Zhang, Z., Castro, J., Demidova, N., Lim, J., Allard, G., Running, S. W., Semerci, A., and Cobb, N.: A global overview of drought and heat-induced tree mortality reveals emerging climate change risks for forests, Forest Ecol. Manag., 259, 660684, https://doi.org/10.1016/j.foreco.2009.09.001, 2010.

Bąk, B. and Kubiak-Wójcicka, K.: Impact of meteorological drought on hydrological drought in Torun (central Poland) in the period of 1971-2015, Journal of Water and Land Development, 32, 3-12, https://doi.org/10.1515/jwld-2017-0001, 2017.

Bąk, B. and Łabędzki, L.: Assessing drought severity with the relative precipitation index (RPI) and the standardized precipitation index (SPI), Journal of Water and Land Development, 6, 89-105, 2002.

Bąk, B., Kejna, M., and Uscka-Kowalkowska, J.: Susze meteorologiczne w rejonie Stacji ZMŚP w Koniczynce (Pojezierze Chełmińskie) w latach 1951-2010 (Meteorological droughts in the area of the ZMŚP Station in Koniczynka (Chełmińskie Lake District) in the years 1951-2010), Woda-Środowisko-Obszary Wiejskie, 12, 19-28, 2012.

Balanzategui, D., Knorr, A., Heussner, K.-U., Wazny, T., Beck, W., Słowiński, M., Helle, G., Buras, A., Wilmking, M., Van Der Maaten, E., Scharnweber, T., Dorado-Liñán, I., and Heinrich, I.: An 810-year history of cold season temperature variability for northern Poland, Boreas, 47, 443-453, https://doi.org/10.1111/bor.12274, 2017.

Bartczak, A., Glazik, R., and Tyszkowski, S.: Identyfikacja i ocena intensywności okresów suchych we wschodniej części Kujaw (Identification and evaluation of the intensity of dry periods in the eastern part of Kujawy), Nauka Przyroda Technologie, 8, 1$22,2014$.

Bartholy, J. and Pongracz, R.: Regional analysis of extreme temperature and precipitation indices for the Carpathian Basin from 1946 to 2001, Global Planet. Change, 57, 83-95, 2007.

Bergemann, J. G.: Beschreibung und Geschichte von Warmbrunn und seinen Heilquellen, J. S. Landolt, Hirschberg, 1830a.

Bergemann, J. G.: Chronik der Stadt Buznlau, Abt. 3, Bunzlau, $1830 \mathrm{~b}$.

Brázdil, R., Trnka, M., Dobrovolný, P., Chromá, K., Hlavinka, P., and Žalud, Z.: Variability of droughts in the Czech Republic, 1881-2006, Theor. Appl. Climatol., 97, 297-315, https://doi.org/10.1007/s00704-008-0065-x, 2007.

Brázdil, R., Trnka, M., Dobrovolný P., Chromá, K., Hlavinka, P., and Žalud, Z.: Variability of droughts in the Czech Republic, 1881-2006, Theor. Appl. Climatol., 97, 297-315, https://doi.org/10.1007/s00704-008-0065-x, 2009. 
Brázdil, R., Dobrovolný, P., Trnka, M., Kotyza, O., Řezníčková, L., Valášek, H., Zahradníček, P., and Štěpánek, P.: Droughts in the Czech Lands, 1090-2012 AD, Clim. Past, 9, 1985-2002, https://doi.org/10.5194/cp-9-1985-2013, 2013.

Brázdil, R., Dobrovolný, P., Trnka, M., Büntgen, U., Řezníčková, L., Kotyza, O., Valášek, H., and Štěpánek, P.: Documentary and instrumental-based drought indices for the Czech Lands back to AD 1501, Clim. Res., 70, 103-117, https://doi.org/10.3354/cr01380, 2016.

Brázdil, R., Kiss, A., Luterbacher, J., Nash, D. J., and Řezníčková, L.: Documentary data and the study of past droughts: a global state of the art, Clim. Past, 14, 1915-1960, https://doi.org/10.5194/cp-14-1915-2018, 2018.

Brewer, S., Alleaume, S., Guiot, J., and Nicault, A.: Historical droughts in Mediterranean regions during the last 500 years: a data/model approach, Clim. Past, 3, 355-366, https://doi.org/10.5194/cp-3-355-2007, 2007.

Bryś, K. and Bryś, T.: Reconstruction of the 217-year (1791-2007) Wrocław air temperature and precipitation series, Bulletin of Geography, Physical Geography Series, 3, 121-171, 2010.

Bunn, A. G.: A dendrochronology program library in $\mathrm{R}$ (dplR), Dendrochronologia, 26, 115-124, https://doi.org/10.1016/j.dendro.2008.01.002, 2008.

Büntgen, U., Brázdil, R., Heussner, K.-U., Hofmann, J., Kontic, R., Kyncl, T. S., Pfister, C., Chromá, K. R., and Tegel, W.: Combined dendro-documentary evidence of Central European hydroclimatic springtime extremes over the last millennium, Quarternary Sc. Rev., 30, 3947-3959, https://doi.org/10.1016/j.quascirev.2011.10.010, 2011.

Büntgen, U., Frank, D. C., Kaczka, R. J., Verstege, A., ZwijaczKozica, T., and Esper, J.: Growth responses to climate in a multi-species tree-ring network in the Western Carpathian Tatra Mountains, Poland and Slovakia, Tree Physiol., 27, 689-702, https://doi.org/10.1093/treephys/27.5.689, 2007.

Büntgen, U., Tegel, W., Carrer, M., Krusic, P. J., Hayes, M., and Esper, J.: Commentary to Wetter et al. (2014): Limited tree-ring evidence for a 1540 European 'Megadrought', Clim. Change, 131, 183-190, https://doi.org/10.1007/s10584-015-1423-1, 2015.

Cook, E., Briffa, K., Shiyatov, S., Mazepa, A., and Jones, P.: Data analysis, in: Methods of dendrochronology: applications in the environmental sciences, edited by: Cook, E. and Kairiukstis, L., International Institute for Applied Systems Analysis, Kluwer, Boston, 97-162, 1990.

Cook, E. R., Woodhouse, C. A., Eakin, C. M., Meko, D. M., and Stahle D. W.: Long-term aridity changes in the western United States, Science, 306, 1015-1018, 2004.

Cook, E. R., Anchukaitis, K. J., Buckley, B. M., D’Arrigo, R. D., Jacoby, G. C., and Wright, W. E.: Asian monsoon failure and megadrought during the last millennium, Science, 328, 486-489, 2010.

Cook, E. R., Seager, R., Kushnir, Y., Briffa, K. R., Büntgen, U., Frank, D., Krusic, P. J., Tegel, W., van der Schrier, G., AndreuHeyles, L., Bailie, M., Baittinger, C., Bleicher, N., Bonde, N., Brown, D., Carrer, M., Cooper, R., Čufar, K., Dittmar, C., Esper, J., Griggs, C., Gunnarson, B., Günther, B., Gutierrez, E., Haneca, K., Helama, S., Herzig, F., Heussner, K.-U., Hofmann, J., Janda, P., Kontic, R., Köse, N., Kyncl, T., Levanič, T., Linderholm, H., Manning, S., Melvin, T. M., Miles, D., Neuwirth, B., Nicolussi, K., Nola, P., Panayotov, M., Popa, I., Rothe, A.,
Seftigen, K., Seim, A., Svarva, H., Svoboda, M., Thun, T., Timonen, M., Touchan, R., Trotsiuk, V., Trouet, V., Walder, F., Ważny, T., Wilson, R., and Zang, C.: Old World megadroughts and pluvials during the Common Era, Science Advances, 1, e150061, https://doi.org/10.1126/sciadv.1500561, 2015.

Čufar, K., De Luis, M., Eckstein, D., and Kajfež-Bogataj, L.: Reconstructing dry and wet summers in SE Slovenia from oak tree-ring series, Int. J. Biometeorol., 52, 607-615, https://doi.org/10.1007/s00484-008-0153-8, 2008.

Dai, A.: Drought under global warming: a review, WIREs Clim Change, 2, 45-65, 2011 a.

Dai, A.: Characteristics and trends in various forms of the Palmer Drought Severity Index during 1900-2008, J. Geophys. Res., 116, D12115, https://doi.org/10.1029/2010JD015541, $2011 \mathrm{~b}$.

Dai, A.: Increasing drought under global warming in observations and models, Nat. Clim. Change, 3, 52-58, 2013.

Dai, A. and Trenberth, K. E.: Global Variations in Droughts and Wet Spells: 1900-1995, Geophys. Res. Lett., 25, 3367-3370, 1998.

Dai, A., Trenberth, K. E., and Qian, T.: A Global Dataset of Palmer Drought Severity Index for 1870-2002: Relationship with Soil Moisture and Effects of Surface Warming, J. Hydrometeorol., 5, 1117-1130, 2004.

Diakowska, E., Stanek, P., Iwański, S., and Gąsiorek, E.: Estimation of the occurrence of drought in Poland by 2060 based on the HTC index and probability distributions, ITM Web Conf., 23, 00006, https://doi.org/10.1051/itmconf/20182300006, 2018.

Dobrovolný, P., Rybníček, M., Kolář, T., Brázdil, R., Trnka, M., and Büntgen, U.: A tree-ring perspective on temporal changes in the frequency and intensity of hydroclimatic extremes in the territory of the Czech Republic since 761 AD, Clim. Past, 11, 1453-1466, https://doi.org/10.5194/cp-11-1453-2015, 2015.

Domínguez-Castro, F., Santisteban, J. I., Barriendos, M., and Mediavilla, R.: Reconstruction of drought episodes for central Spain from rogation ceremonies recorded at the Toledo Cathedral from 1506 to 1900: a methodological approach, Global Planet. Change, 63, 230-242, 2008.

Domínguez-Castro, F., García-Herrera, R., Ribera, P., and Barriendos, M.: A shift in the spatial pattern of Iberian droughts during the 17th century, Clim. Past, 6, 553-563, https://doi.org/10.5194/cp-6-553-2010, 2010.

Doroszewski, A., Kozyra, J., Pudełko, R., Stuczyński, T., Jadczyszyn, J., Koza, P., and Łopatka, A.: Monitoring suszy rolniczej w Polsce (Monitoring of agricultural drought in Poland), Wiadomości Melioracyjne i Łąkarskie, 1, 35-38, 2008.

Doroszewski, A., Jadczyszyn, J., Kozyra, J., Pudełko, R., Stuczyński, T., Mizak, K., Łopatka, A., Koza, P., Górski, T., and Wróblewska E.: Podstawy systemu monitoringu suszy rolniczej (The basics of agricultural drought monitoring system), WodaŚrodowisko-Obszary Wiejskie, 12, 77-91, 2012.

Dove, H. W.: Bericht über die in den Jahren 1848 und 1849 auf den Stationen des Meteorologischen Instituts im Preussen Staate angestellen Beobachtungen, Berlin, 1851.

Ephemerides Societatis Meteorologicae Palatinae: Observationes 1781-1792, Ex Officina Novae Societatis Typographicae, vol. IIXIII, Mannheim, 1783-1795.

Farat, R., Kepinska-Kasprzak, M., Kowalczak, P., and Mager, P.: Droughts in Poland, 1951-90, Drought Network News (1994-2001), 42, available at: https://digitalcommons.unl.edu/ droughtnetnews/42/ (last access: 4 March 2020), 1998. 
Filipiak, J.: Obserwacje i pomiary opadów atmosferycznych w Gdańsku w XVIII wieku (Observations and measurements of precipitation in Gdańsk in the 18th century), in: Wahania klimatu w różnych skalach przestrzennych i czasowych, edited by: Piotrowicz, K. and Twardosz, R., UJ, Kraków, Poland, 365-373, 2007.

Filipiak, J.: Długookresowa zmienność opadów atmosferycznych w Gdańsku w okresie 1880-2010 (Long-term variability of atmospheric precipitation in Gdańsk in the period 1880-2010), Prace i Studia Geograficzne, Uniwersytet Warszawski, 47, 119-128, 2011.

Filipiak, J., Przybylak, R., and Oliński, P.: The longest oneman weather chronicle (1721-1786) by Gottfried Reyger for Gdańsk, Poland as a source for improved understanding of past climate variability, Int. J. Climatol., 39, 828-842, https://doi.org/10.1002/joc.5845, 2019.

Fragoso, M., Carraça, M. G., and Alcoforado, M. J.: Droughts in Portugal in the 18th century: A study based on newly found documentary data, Int. J. Climatol., 38, 5522-5541, 2018.

Fritts, H.: Tree rings and climate, Academic Press, London, UK, 1976.

Girguś, R., Strupczewski, W., and Rojecki, A.: Wyjątki ze źródeł historycznych o nadzwyczajnych zjawiskach hydrologicznometeorologicznych na ziemiach polskich w wiekach od $\mathrm{X}$ do XVI (Exceptions from historical sources about extraordinary hydrological and meteorological phenomena in Polish lands from the 10th to the 16th centuries), Wydawnictwa Komunikacji i Łączności, Warszawa, Poland, 1965.

Greve, P., Orlowsky, B., Mueller, B, Sheffel, J., Reichstein, M., and Seneviratne, S. I.: Global assessment of trends in wetting and drying over land, Nat. Geosci., 7, 716-721, https://doi.org/10.1038/ngeo2247, 2014.

Hanel, M., Rakovec, O., Markonis, Y., Máca, P., Samaniego, L., Kyselý, J., and Kumar, R.: Revisiting the recent European droughts from a long-term perspective, Scientific Reports, 8, 9499, https://doi.org/10.1038/s41598-018-27464-4, 2018.

Hanow, M. C.: Wetterbeobachtungen in Danzig von aus Jahren 1739 bis 1773, Volumes 1-3, Manuscript, 1773.

Helama, S. and Lindholm, M.: Droughts and rainfall in southeastern Finland since AD 874 , inferred from Scots pine, BOREAL Environ. Res., 8, 171-183, 2003.

Helama, S., Holopainen, J., Timonen, M., and Mielikäinen, K.: An 854-year tree-ring chronology of scots pine for south-west Finland, Studia Quaternaria, 31, 61-68, 2014.

Held, I. M., Delworth, T. L., Lu, J., Findell, K. L., and Knutson, T. R.: Simulation of Sahel drought in the 20th and 21st centuries, P. Natl. Acad. Sci. USA, 102, 17891-17896, 2005.

Hellmann, C.: Repertorium der deutschen Meteorologie, Verlag von Wilhelm Engelmann, Leipzig, 1883.

Herweijer, C., Seager, R., Cook, E. R., and Emile-Geay, J.: North American Droughts of the Last Millennium from a Gridded Network of Tree-Ring Data, J. Climate, 20, 1353-1375, 2007.

IMGW: Drought monitoring system "POSUCH@”, available at: http://posucha.imgw.pl/ (last access: 4 March 2020), 2014.

IMGW-PIB: Climate Monitoring Bulletin of Poland, ISSN 2391-6362, available at: http://klimat.pogodynka.pl/ biuletyn-monitoring/, last access: 4 March 2020.

Inglot, S.: Zjawiska klimatyczno-meteorologiczne na Śląsku od XVI do połowy XIX wieku, in: Z badań nad wpływem po- suchy na rolnictwo na Dolnym Śląsku (Climatic and Meteorological Phenomena in Silesia from the 16th to the mid-19th century), edited by: Świętochowski, B., Wrocławskie Towarzystwo Naukowe, Wrocław, 9-52, 1968.

IPCC: Climate Change 2013: The Physical Science Basis. IPCC Working Group I Contribution to Fifth Assessment Report of the Intergovernmental Panel on Climate Change, Cambridge University Press, Cambridge, United Kingdom and New York, NY, 2013.

IPCC: Climate Change 2014: Impacts, Adaptation, and Vulnerability, Part A: Global and Sectoral Aspects, in: Contribution of Working Group II to the Fifth Assessment Report of the Intergovernmental Panel on Climate Change, edited by: Field, C. B., Barros, V. R., Dokken, D. J., Mach, K. J., Mastrandrea, M. D., Bilir, T. E., Chatterjee, M., Ebi, K. L., Estrada, Y. O., Genova, R. C., Girma, B., Kissel, E. S., Levy, A. N., MacCracken, S., Mastrandrea, P. R., and White, L. L., Cambridge University Press, Cambridge, UK and New York, NY, USA, 1132 pp., 2014.

ITP: System "Monitoring and forecasting water deficit and surplus in agriculture", available at: http://agrometeo.itp.edu.pl/ (last access: 4 March 2020), 2014.

Jevšenak, J. and Levanič, T.: dendroTools: R package for studying linear and nonlinear responses between tree-rings and daily environmental data, Dendrochronologia, 48, 32-39, https://doi.org/10.1016/j.dendro.2018.01.005, 2018.

Kaca, E., Stąpel, Z., and Śniadowski Z.: Gospodarka wodna w rolnictwie w świetle suszy 1992 roku (Water management in agriculture in the light of drought in 1992), Materiały Informacyjne IMUZ, 22, Warsaw, Poland, 1993.

Kalbarczyk, R.: Temporal and spatial diversity of the occurrence of atmospheric drought in Poland (1966-2005) and its effect of yield of pickling cucumber (Cucumis sativus L.), Spanish J. Agric. Res., 8, 1147-1162, 2010.

Koprowski, M., Przybylak, R., Zielski, A., and Pospieszyńska, A.: Tree rings of Scots pine (Pinus sylvestris L.) as a source of information about past climate in northern Poland, Int. J. Biometeorol., 56, 1-10, https://doi.org/10.1007/s00484-010-0390-5, 2012.

Kożuchowski, K.: Zmienność opadów atmosferycznych w Polsce w stuleciu 1881-1980 (Variability of atmospheric precipitation in Poland in the 1881-1980 century), Acta Geographica Lodziensia, 48, 158 pp., 1985.

Kożuchowski, K. and Miętus, M.: Historia zmian klimatu w Szczecinie (History of climate change in Szczecin), in: Współczesne zmiany klimatyczne. Klimat Szczecina i współczesne zmiany klimatyczne w rejonie Morza Bałtyckiego, edited by: Kożuchowski, K., Uniwersytet Szczeciński, Rozprawy i Studia, 98, 45-60, 1996.

Kożuchowski, K. and Żmudzka, E.: 100 year series of the areally averaged temperatures and precipitation totals in Poland, in: Men and Climate in the 20th century, edited by: Pyka, L. J., Acta Univ. Wratislav., 2542, Stud. Geogr., 75, 116-222, 2003.

Larocque-Tobler, I., Filipiak, J., Tylmann, W., Bonk, A., and Grosjean, M.: Comparison between chironomid-inferred meanAugust temperature from varved Lake Żabińskie (Poland) and instrumental data since 1896 AD, Quaternary Sci. Rev., 111, 3550,2015

Liang, W., Heinrich, I., Simard, S., Helle, G., Liñán, I. D., and Heinken, T.: Climate signals derived from cell anatomy 
of Scots pine in NE Germany, Tree Physiol., 33, 833-844, https://doi.org/10.1093/treephys/tpt059, 2013.

Limanówka, D.: Rekonstrukcja warunków klimatycznych Krakowa w pierwszej połowie XVI wieku (Reconstruction of climatic conditions in Cracow in the first half of the 16th century), Materiały Badawcze IMGW, Seria: Meteorologia, 33, 1-176, 2001.

Liszewska, M., Konca-Kędzierska, K., Jakubiak, B., and

Śmiałecka, E.: Opracowanie scenariuszy zmian klimatu dla Polski i wybranych regionów (Development of climate change scenarios for Poland and selected regions), Report 2, KLIMADA project, ICM, Warsaw, 54 pp., 2012.

Lorenc, H.: Studia nad 220-letnią (1779-1998) serią temperatury powietrza w Warszawie oraz ocena jej wiekowych tendencji (Studies on 220-year-old (1779-1998) series of air temperature in Warsaw and assessment of its tendencies), Materiały Badawcze IMGW, seria: Meteorologia, 31, 1-104, 2000.

Lorenc, H. (Ed.): Atlas klimatu Polski (Climate of Poland Atlas), Instytut Meteorologii i Gospodarki Wodnej, Warszawa, 2005.

Lorenc, H.: Długookresowe zmiany opadów atmosferycznych oraz maksymalnej i minimalnej temperatury powietrza w Warszawie (Long-term changes of monthly precipitation and maximum and minimum air temperature in Warsaw), Sprawozdanie $\mathrm{z}$ tematu badawczego DSK IMGW, 2007 (unpublished).

Łabędzki, L.: Susze rolnicze - zarys problematyki oraz metody monitorowania i klasyfikacji (Agricultural drought - an outline of the problems and methods of monitoring and classification), Woda-Środowisko-Obszary Wiejskie, Rozpr. Nauk. i Monografie, 17, 107 pp., 2006.

Łabędzki, L.: Estimation of local drought frequency in Central Poland using the standardized precipitation index SPI, Irrig. Drain., 56, 67-77, 2007.

Łabędzki, L.: Susze-potencjalne straty w plonach i sposoby przeciwdziałania, Odnawialne źródła energii i działania adaptacyjne do zmian klimatu w rolnictwie i na wsi - przykłady doświadczeń w UE (Drought-potential yield losses and counteracting measures, Renewable energy sources and adaptation measures to climate change in agriculture and the countryside - examples of experiences in the EU), edited by: Grzybek A., Scholar, Warszawa, Poland, 103-117, 2009.

Łabędzki, L. and Bąk, B.: Meteorological and agricultural drought indices used in drought monitoring in Poland: A review, Meteorology Hydrology and Water Management, 2, 3-14, 2014.

Łabędzki, L. and Kanecka-Geszke, E.: Standardized evapotranspiration as an agricultural drought index, Irrig. Drain., 58, 607616, https://doi.org/10.1002/ird.421, 2009.

Łabędzki, L., Bąk, B., Kanecka-Geszke, E., Kasperska-Wołowicz, W., Smarzyńska, K.: Związek między suszą meteorologiczną i rolniczą w różnych regionach agroklimatycznych Polski (The relationship between meteorological and agricultural drought in various agroclimatic regions of Poland), Wydawnictwo IMUZ, 25, 132 pp., 2008.

Magier, P., Kuźnicka, M., Kępińska-Kasprzak, M., and Farat, R.: Changes in the intensity and frequency of occurrence of droughts in Poland (1891-1995), Geographia Polonica, 73, 41-47, 2000.

Malewicz, H. M.: Zjawiska przyrodnicze w relacjach dziejopisarzy polskiego średniowiecza (Natural Events in Reports by the Historians of Medieval Poland), Zakład Narodowy im. Ossolińskich, Wrocław-Warszawa-Kraków-Gdańsk, 1980.
Maliszewski, K.: Obraz świata przyrody w kulturze staropolskiej. Egzemplifikacja zagadnienia na podstawie gazet pisanych (An image of the natural world in Old Polish culture. Exemplification of the issue based on written newspapers), in: Historia-klimatprzyroda. Perspektywa antropocentryczna (Natura, Homines, Historia. Studia z historii środowiskowej, vol. 1), edited by: Oliński, P. and Piasek, W., 135-166, 2018.

McKee, T. B., Doesken, N. J., and Kleist, J.: The relationship of drought frequency and duration to time scales, in: Proceedings of the 8th Conference on Applied Climatology, Anaheim, 17-22 January 1993, 17, 179-183, 1993.

Miętus, M.: Zmienność temperatury i opadów w rejonie polskiego wybrzeża Morza Bałtyckiego i jej spodziewany przebieg do roku 2030 (Long-term variation of temperature and precipitation on the Polish coast and expected changes until 2030), Materiały Badawcze IMGW, Seria: Meteorologia, 26, 1-72, 1996.

Miętus, M.: O ciągłości i jednorodności wieloletnich serii klimatologicznych na przykładzie rezultatów pomiarów w Koszalinie (On continuity and homogeneity of long-term climatological series on the example of measurement results in Koszalin), in: Działalność naukowa Prof. Wł. Gorczyńskiego i jej kontynuacja, edited by: Wójcik, G. and Marciniak, K., UMK Toruń, 321-336, 2002.

Miles, D., Neuwirth, B., Nicolussi, K., Nola, P., Panayotov, M., Popa, I., Rothe, A., Seftigen, K., Seim, A., Svarva, H., Svoboda, M., Thun, T., Timonen, M., Touchan, R., Trotsiuk, V., Trouet, V., Walder, F., Ważny, T., Wilson, R., and Zang, C.: Old world megadroughts and pluvials during the common era, Science Advances, 1, e1500561, https://doi.org/10.1126/sciadv.1500561, 2015.

Mishra, A. K. and Singh, V. P.: A review of drought concepts, J. Hydrol., 391, 202-216, 2010.

Namaczyńska, S.: Kronika klęsk elementarnych w Polsce i w krajach sąsiednich w latach 1648-1696 (Chronicle of elementary events in Poland and in neighbouring countries in the years 1648-1696), Wyd. Polska B. Wysłoucha, Lwów, 1937.

NAS: Polish National Strategy for Adaptation to Climate Change (NAS 2020) with the perspective by 2030, Ministry of the Environment, Republic of Poland, Warsaw, available at: https://klimada.mos.gov.pl/wp-content/uploads/2014/12/ ENG_SPA2020_final.pdf (last access: 4 March 2020), 2013.

Neuwirth, B., Schweingruber, F. H., and Winiger, M.: Spatial patterns of central European pointer years from 1901 to 1971, Dendrochronologia, 24, 79-89, https://doi.org/10.1016/j.dendro.2006.05.004, 2007.

Niedźwiedź, T., Glaser, R., Hansson, D., Helama, S., Klimenko, V., Łupikasza, E., Małarzewski, Ł., Nordli, Ø., Przybylak, R., Riemann, D., and Solomina, O.: The Historical Time Frame (Past 1000 Years), in: The BACC II Author Team, Second Assessment of Climate Change for the Baltic Sea Basin, Regional Climate Studies, Springer Open, 51-65, https://doi.org/10.1007/978-3319-16006-1_3, 2015.

Nowosad, W. and Oliński, P.: The extreme year of 1540 in terms of climate variation from the perspective of historical sources derived from the Polish and Baltic territories, in: Dance of Death, edited by: Kiss, A. and Pribyl, K., 146-155, 2019.

Nowosad, W., Przybylak, R., Marciniak, K., and Syta, K.: Diariusz Jana Antoniego Chrapowickiego jako źródło do badań klimatu Rzeczypospolitej w drugiej połowie XVII wieku (Diary of Jan 
Antoni Chrapowicki as a source for research on the climate of the Commonwealth in the second half of the 17 th century), Klio, 9, 21-60, 2007.

Oliński, P.: Warunki pogodowe w Toruniu i okolicach w 1. połowie XVIII wieku w świetle źródeł narracyjnych (Weather conditions in Torun and its surroundings in the 1st half of the eighteenth century in the contextof narrative sources), Rocznik Toruński, 29, 49-85, 2002.

Opała, M.: The 443-Year Tree-Ring Chronology for the Scots Pine from Upper Silesia (Poland) as A Dating Tool and Climate Proxy, Geochronometria, 42, 41-52, https://doi.org/10.1515/geochr2015-0005, 2015.

Opała, M. and Mendecki, M. J.: An attempt to dendroclimatic reconstruction of winter temperature based on multispecies treering widths and extreme years chronologies (example of Upper Silesia, Southern Poland), Theor. Appl. Climatol., 115, 73-89, https://doi.org/10.1007/s00704-013-0865-5, 2014.

Osuch, M., Kindler, J., Romanowicz, R. J., Berbeka, K., and Banrowska, A.: KLIMADA Strategia adaptacji Polski do zmian klimatu w zakresie sektora "Zasoby i gospodarka wodna" (Strategy for Poland's adaptation to climate change in the sector of "Water resources and management"). KLIMADA project, IGF PAN, Warsaw, 245 pp., 2012.

Osuch, M., Romanowicz, R. J., Lawrence, D., and Wong, W. K.: Trends in projections of standardized precipitation indices in a future climate in Poland, Hydrol. Earth Syst. Sci., 20, 19471969, https://doi.org/10.5194/hess-20-1947-2016, 2016.

Paszyński, J. and Niedźwiedź, T.: Klimat (Climate), Chap. 3.3 in: Geografia Polski - środowisko przyrodnicze, edited by: Starkel, L., Wydawn. Naukowe PWN, Warszawa, 296-355, 1991.

Pfister, C., Weingartner, R., and Luterbacher, J.: Hydrological winter droughts over the last 450 years in the Upper Rhine basin: a methodological approach, Hydrolog. Sci. J., 51, 966-985, https://doi.org/10.1623/hysj.51.5.966, 2006.

Pfister, C., Wetter, O., Brázdil, R., Dobrovolný, P., Glaser, R., Luterbacher, J., Seneviratne, S. I., Zorita, E., Alcoforado, M.-J., Barriendos, M., Bieber, U., Burmeister, K. H., Camenisch, C., Contino, A., Grünewald, U., Herget, J., Himmelsbach, I., Labbé, T., Limanówka, D., Litzenburger, L., Kiss, A., Kotyza, O., Nordli, Ø., Pribyl, K., Retsö, D., Riemann, D., Rohr, C., Siegfried, W., Spring, J.-L., Söderberg, J., Wagner, S., and Werner, J. P.: Tree rings and people - different view on the 1540 Megadrought. Reply to Büntgen et al. 2015, Clim. Change, 131, 191-198, https://doi.org/10.1007/s10584-015-1429-8, 2015.

Piervitali, E. and Colacino, M.: Evidence of drought in western Sicily during the period 1565-1915 from liturgical offices, Clim. Change, 49, 225-238, 2001.

Pospieszyńska, A. and Przybylak, R.: Ekstremalne warunki klimatyczne w Toruniu w okresie pomiarów instrumentalnych 1871-2010 (Extreme weather conditions in Torun during the instrumental measurements period, 1871-2010), in: Od

powietrza, głodu, ognia i wojny... : klęski elementarne na przestrzeni wieków : Wrocławskie Spotkania z Historią Gospodarczą - Spotkanie VIII, edited by: Głowiński, T. and Kościk, E., GAJT Wydawnictwo, 187-196, 2013.

Pritzkow, C., Wazny, T., Heußner, K. U., Słowiński, M., Bieber, A., Liñán, I. D., Helle, G., and Heinrich, I.: Minimum winter temperature reconstruction from average earlywood vessel area of European oak (Quercus robur) in N-Poland, Palaeogeogr. Palaeocl.,
449, 520-530, https://doi.org/10.1016/j.palaeo.2016.02.046, 2016.

Pruchnicki, J.: Metody opracować klimatologicznych (Methods of climatological studies), Państwowe Wydawnictwo Naukowe, Warszawa, 1987.

Przybylak, R.: Changes in Poland's climate over the last millennium, Czasop. Geogr., 82, 23-48, 2011.

Przybylak, R.: Poland's Climate in the Last Millennium, Oxford Research Encyclopedia, Climate Science, Oxford University Press, USA, 36 pp., https://doi.org/10.1093/acrefore/9780190228620.013.2, 2016.

Przybylak, R. and Marciniak, K.: Climate Changes in the Central and North-eastern Parts of the Polish-Lithuanian Commonwealth from 1656 to 1685, in: The Polish Climate in the European Context. An Historical Overview, edited by: Przybylak, R., Majorowicz, J., Brázdil, R., and Kejna, M., Springer, Dordrecht, Heidelberg, London, New York, 423-443, https://doi.org/10.1007/97890-481-3167-9, 2010.

Przybylak, R., Wójcik, G., and Majorowicz, J.: Zmiany temperatury powietrza i opadów atmosferycznych w Polsce w okresie XVI-XX wiek (Changes of air temperature and atmospheric precipitation in Poland from 16th to 20th century), Prace i Studia Geograficzne, 29, 79-92, 2001.

Przybylak, R., Wójcik, G., Marciniak, K., Chorążyczewski, W., Nowosad, W., Oliński, P., and Syta, K.: Zmienność warunków termiczno-opadowych w Polsce w okresie 1501-1840 w świetle danych historycznych (Variability of thermal and precipitation conditions in Poland from 1501 to 1840 based on historical sources), Przegl. Geograficzny, 76, 5-31, 2004.

Przybylak, R., Majorowicz, J., Wójcik, G., Zielski, A., Chorążyczewski, W., Marciniak, K., Nowosad, W., Oliński, P., and Syta, K.: Temperature changes in Poland from the 16th to the 20th centuries, Int. J. Climatol., 25, 773-791, https://doi.org/10.1002/joc.1149, 2005.

Przybylak, R., Oliński, P., Chorążyczewski, W., Nowosad, W., and Syta, K.: The Climate of Poland in Recent Centuries: A Synthesis of Current Knowledge: Documentary evidence, in: The Polish Climate in the European Context. An Historical Overview, edited by: Przybylak, R., Majorowicz, J., Brázdil, R., and Kejna, M., Springer, Dordrecht, Heidelberg, London, New York, 167-190, https://doi.org/10.1007/978-90-481-3167-9, 2010.

Przybylak, R., Pospieszyńska, A., Wyszyński, P., and Nowakowski, M.: Air temperature changes in Żagan (Poland) in the period from 1781 to 1792, Int. J. Climatol., 34, 2408-2426, 2014.

Przybylak, R., Oliński, P., Filipiak, J., Pospieszyńska, A., and Chorążyczewski, W.: Drought indices for the area of Poland, RepOD, https://doi.org/10.18150/repod.3621839, 2020.

Puchałka, R., Koprowski, M, Przybylak, J., Przybylak, R., and Dąbrowski, H.: Did the late spring frost in 2007 and 2011 affect tree-ring width and earlywood vessel size in Pedunculate oak (Quercus robur) in northern Poland?, Int. J. Biometeorol., 60, 1143-1150, https://doi.org/10.1007/s00484-015-1107-6, 2016.

Radzka, E.: The assessment of atmospheric drought during vegetation season (according to standardized precipitation index SPI) in central-eastern Poland, Journal of Ecological Engineering, 16, 87-91, https://doi.org/10.12911/22998993/591, 2015.

$\mathrm{R}$ Core Team: R: a language and environment for statistical computing, available at: https://www.r-project.org/ (last access: 4 March 2020), 2019. 
Reichsamt für Wetterdienst: Klimakunde des Deutschen Reiches. Band II Tabellen mit Karten. Verlag von Dietrich Reimer, Andrews\&Steiner, Berlin, 560 pp., 1939.

Reinhold, W.: Chronik der Stadt Soldin von der ältesten bis auf neueste Zeit, Soldin, 1846.

Reyger, G.: Die Beschaffenheit der Witterung in Danzig vom Jahre 1722-1769 beobachtet, nach ihren Veränderungen und Ursachen erwogen, und mit dem Wetter anderer Orten verglichen, Daniel Ludwig Wedel Press, Gdańsk, Leipzig, 520 pp., 1770.

Reyger, G.: Die Beschaffenheit der Witterung in Danzig vom Jahre 1770-1786 beobachtet, nach ihren Veränderungen und Ursachen erwogen, und mit dem Wetter anderer Orten verglichen, Daniel Ludwig Wedel Press, Gdańsk, 200 pp. (c.a.), 1788.

Rojecki, A.: Kilka uwag o najdawniejszych obserwacjach meteorologicznych w Toruniu na tle wyników jednocześnie prowadzonych spostrzeżeń w Warszawie (A few remarks about the earliest meteorological observations in Torun against the background of the results of simultaneous observations in Warsaw), Przegląd Geofizyczny X, 141-151, 1965.

Sadowski, M.: Variability of extreme climatic events in Central Europe since the 13th century, Z. Meteorol., 41, 350-356, 1991.

Scharnweber, T., Heußner, K.-U., Smiljanic, M., Heinrich, I., van der Maaten-Theunissen, M., van der Maaten, E., Struwe, T., Buras, A., and Wilmking, M.: Removing the no-analogue bias in modern accelerated tree growth leads to stronger medieval drought, Sci. Rep., 9, 2509, https://doi.org/10.1038/s41598-01939040-5, 2019.

Seftigen, K., Linderholm, H. W., Drobyshev, I., and Niklasson, M.: Reconstructed drought variability in southeastern Sweden since the 1650s, Int. J. Climatol., 33, 2449-2458, 2013.

Seneviratne, S. I., Nicholls, N., Easterling, D., Goodess, C. M., Kanae, S., Kossin, J., Luo, Y., Marengo, J., McInnes, K., Rahimi, M., Reichstein, M., Sorteberg, A., Vera, C., and Zhang, X.: Changes in climate extremes and their impacts on the natural physical environment, in: Managing the Risks of Extreme Events and Disasters to Advance Climate Change Adaptation, A Special Report of Working Groups I and II of the Intergovernmental Panel on Climate Change (IPCC), edited by: Field, C. B., Barros, V., Stocker, T. F., Qin, D., Dokken, D. J., Ebi, K. L., Mastrandrea, M. D., Mach, K. J., Plattner, G.-K., Allen, S. K., Tignor, M., and Midgley, P. M., Cambridge University Press, Cambridge, UK, and New York, NY, USA, 109-230, 2012.

Sheffield, J., Wood, E. F., and Roderick, M. L.: Little change in global drought over the past 60 years, Nature, 491, 435-438, 2012.

Słota, H., Bobiński, E., Dobrowolski, A., Fal, B., Gałka, S., Korol, R., Lorenc, H., Mierkiewicz, M., Rutkowski, Z., Tomaszewska, T., and Żelaziński, J.: Susza 1992. Zasięg, natężenie, przyczyny i skutki, wnioski na przyszłość (Drought 1992. Range, intensity, causes and effects, conclusions for the future), Instytut Meteorologii i Gospodarki Wodnej, Warszawa, Poland, 1992.

Sohar, K., Helama, S., Läänelaid, A., Raisio, J., and Tuomenvirta, H.: Oak decline in a southern Finnish forest as affected by a drought sequence, Geochronometria, 41, 92-103, https://doi.org/10.2478/s13386-013-0137-2, 2013.

Somorowska, U.: Changes in Drought Conditions in Poland over the Past 60 Years Evaluated by the Standardized PrecipitationEvapotranspiration Index, Acta Geophys., 64, 2530-2549, https://doi.org/10.1515/acgeo-2016-0110, 2016.
Štěpánek, P., Zahradníček, P., and Skalák, P.: Data quality control and homogenization of air temperature and precipitation series in the area of the Czech Republic in the period 1961-2007, Adv. Sci. Res., 3, 23-26, https://doi.org/10.5194/asr-3-23-2009, 2009.

Szewczuk, J: Kronika klęsk elementarnych w Galicji w latach 1772-1848 (Chronicle of elementary events in Galicia in the years 1772-1848), Badania z Dziejów Społecznych i Gospodarczych, wyd. Kasa im. Mianowskiego w Warszawie, Lwów, 35 pp., 1939.

Szychowska-Krapiec, E.: Long-term chronologies of pine (Pinus sylvestris L.) and fir (Abies alba Mill.) from the Małopolska Region and their paleoclimatic interpretation, Folia Quaternaria, 79, 5-124, 2010.

Tate, E. L. and Gustard, A.: Drought definition: a hydrological perspective, in: Drought and Drought Mitigation in Europe, edited by: Vogt, J. V. and Somma, F., Kluwer, Dordrecht, 23-48, 2000.

Tokarczyk, T.: Classification of low flow and hydrological drought for a river basin, Acta Geophys., 61, 404-421, 2013.

Tokarczyk, T. and Szalińska, W.: The operational drought hazard assessment scheme - performance and preliminary results, Arch. Environ. Prot., 39, 61-77, 2013.

Tokarczyk, T. and Szalińska, W.: Combined analysis of precipitation and water deficit for drought hazard assessment, Hydrolog. Sci. J., 59, 1675-1689, 2014.

Twardosz, R.: Dobowy przebieg opadów atmosferycznych w ujęciu synoptycznym i probabilistycznym na przykładzie Krakowa (1886-2002) (The daily course of precipitation in synoptic and probabilistic terms on the example of Krakow (1886-2002)), UJ IGiGP, Kraków, 2005.

Twardosz, R.: Opady atmosferyczne (Atmospheric precipitation), in: Klimat Krakowa w XX wieku, edited by: Matuszko D., UJ, Kraków, 127-152, 2007.

Vitas, A.: Drought of 1992 in Lithuania and Consequences to Norway Spruce, Balt. For., 7, 25-30, 2001.

Walawender, A.: Kronika klęsk elementarnych w Polsce i w krajach sassiednich w latach 1450-1586 (Chronicle of elementary events in Poland and in neighboring countries in the years 1450-1586), Lwów-Warszawa, Poland, 1935.

Ważny, T.: Aufbau und Anwendung der Dendrochronologie für Eichenholz in Polen, Dissertation, zur Erlangung des Doktorgrades des Fachbereichs Biologie der Universität Hamburg, Germany, 1990.

Wernicke, J. E.: Geschichte Thorns aus Urkunden, Dokumenten und Handschriften, Thorn, Vol. 2, 1842.

Wetter, O., Pfister, C., Werner, J. P., Zorita, E., Wagner, S., Seneviratne, S. I., Herget, J., Grünewald, U., Luterbacher, J., Alcoforado, M.-J., Barriendos, M., Bieber, U., Brázdil, R., Burmeister, K. H., Camenisch, Ch., Contino, A., Dobrovolný, P., Glaser, R., Himmelsbach, I., Kiss, A., Kotyza, O., Labbé, Th., Limanówka, D., Litzenburger, L., Nordl, Ø., Pribyl, K., Retsö, D., Riemann, D., Rohr, Ch., Siegfried, W., Söderberg, J., and Spring, J.-L.: The year-long unprecedented European heat and drought of 1540 - a worst case, Climatic Change, 125, 349-363, https://doi.org/10.1007/s10584-014-1184-2, 2014.

Wilhite, D. A. and Glantz, M. H.: Understanding the drought phenomenon: the role of definitions, Water Int., 10, 111-120, 1985.

White, S., Pfister, Ch., and Mauelshagen, F. (Eds.): The Palgrave Handbook of Climate History, Palgrave Macmillan, London, 2018. 
Wójcik, G., Majorowicz, J., Marciniak, K., Przybylak, R., Šafanda, J., and Zielski, A.: The last millennium climate change in Northern Poland derived from well temperature profiles, tree-rings and instrumental data, Prace Geograficzne, 107, 137-148, 2000.

Woodhouse, C. A., Mekob, D. M., MacDonald, G. M., Stahled, D. W., and Cooke, E. R.: A 1,200-year perspective of 21st century drought in southwestern North America, P. Natl. Acad. Sci. USA, 107, 21283-21288, 2010.

Woś, A.: Klimat Polski (Climate of Poland), Wydawn. Naukowe PWN, Warszawa, 1999.

Wypych, A., Palarz, A., and Kubacka, D.: Spatial differentiation and drought intensity in the Upper Silesia Region, Poland, in: Air and water components of the environment, edited by: Pandi, G. and Moldovan, F., Cluj University Press, Romania, 64-71, 2015.
Zang, C. and Biondi, F.: Treeclim: an R package for the numerical calibration of proxy-climate relationships, Ecography, 38, 431436, https://doi.org/10.1111/ecog.01335, 2015.

Zielony, R. and Kliczkowska, A.: Regionalizacja przyrodniczoleśna Polski 2010 (Regionalization of natural forests in Poland 2010), Centrum Informacyjne Lasów Państwowych, Warszawa, 2010.

Zielski, A., Krąpiec, M., and Koprowski, M.: Dendrochronological Data, in: The Polish Climate in the European Context. An Historical Overview, edited by: Przybylak, R., Majorowicz, J., Brázdil, R., and Kejna, M., Dordrecht, Heidelberg, London, New York, 191-218, https://doi.org/10.1007/978-90-481-3167-9, 2010. 